\title{
THE SYRIAC TRADITION OF THE LEGEND OF THE THIRTY PIECES OF SILVER
}

\author{
TONY BURKE \\ YORK UNIVERSITY, TORONTO, CANADA \\ SLAVOMÍR ČÉPLÖ \\ CHARLES UNIVERSITY, CZECH REPUBLIC / COMENIUS \\ UNIVERSITY, SLOVAKIA
}

\begin{abstract}
Since the publication of the long-lost Gospel of Judas in 2006, there has been a flurry of interest in canonical and noncanonical traditions about the famous betrayer of Christ. One text overlooked in this excitement is the Legend of the Thirty Pieces of Silver (Leg. Silv.), which traces the transmission of the coins paid to betray Jesus from Terah's gift of the coins to Abraham up to Judas's purchase of the Field of Blood in Acts 1:18-19. Leg. Silv. was a very popular text in medieval times and appears in a number of languages and forms, including Latin, Syriac, and Armenian, along with several European languages: German, English, Italian, Spanish, and Catalan. To date, relatively little work has been done on this text; indeed, there has yet to appear a formal critical edition. This paper aims to address this neglect by presenting, for the first time, an edition of the Syriac branch of the tradition. The text is extant in at least eight Syriac manuscripts, another six in Garšuni, and it is found also incorporated into the Book of the Bee by
\end{abstract}


Solomon of Basra. The paper includes also an overview of previous scholarship on Leg. Silv. and a discussion of the text's origins and transmission.

The Legend of the Thirty Pieces of Silver (Leg. Silv.) is a medieval apocryphon that traces the transmission of the coins paid to Judas to betray Jesus from Terah's gift of the coins to Abraham to Judas's purchase of the Field of Blood in Acts 1:18-19. The text is extant in a variety of forms and languages including Latin, Syriac, Armenian, and several European languages including German, English, Italian, Spanish, and Catalan. Previous work on the text has focused primarily on the versions in Western languages, neglecting the Eastern branch of the tradition. Of these Eastern traditions, the Syriac is by far the most plentiful-eleven manuscripts feature Leg. Silv. as a distinct text, and another 12 contain the text as part of Solomon of Basra's Book of the Bee. Few of these manuscripts have seen publication, and until now no critical edition of the Syriac tradition has appeared. With such an edition it is possible to determine the shape and proclivities of the text as it was read in the East and to consider how it relates to Leg. Silv. in Western sources.

The theme of the tale is fate. Through almost two millennia, the coins are kept together as a unit and providentially guided to their ultimate goal. ${ }^{1}$ Along the way they figure in several major events in biblical history, including the sale of Joseph, the construction of Solomon's temple, and the Babylonian Exile. From Babylon, the coins make their way to Palestine via a number of channels, but ultimately arrive there either among the gifts of the Magi (in the Western texts) or as the gift of King Abgar of Edessa (in the Eastern texts). Jesus gives the coins to the Temple, and the Jews then use them to pay Judas to betray Jesus. Finally, the coins are used to purchase the potter's field. The story of an object's passage through history to its predestined goal is taken up in traditions of other auspicious items found in the gospels, including the gifts of the Magi, the cross of Jesus, the purple cloak, and the Seamless Robe, the last of which is incorporated in the story of Leg.

${ }^{1}$ Kim Paffenroth, Judas: Images of the Lost Disciple (Louisville, Ky.: Westminster/John Knox, 2001), 79. 
Silv. in several witnesses. Such translation narratives provide back stories to their related relics-whether real (however unlikely) or counterfeit-and allow the bearer of such relics to feel that their ownership or stewardship of the holy object is also providentially ordained. They become part of the story.

\section{THE LEGEND IN WESTERN SOURCES}

The earliest evidence for the text of Leg. Silv. in the West appears in the works of three writers. ${ }^{2}$ The first of these works is Godfrey of Viterbo's Pantheon, a world chronicle dedicated to Henry VI recording the history of the world from creation until 1185, the year of its completion. ${ }^{3}$ Godfrey died six years later. The text, a mixture of Latin prose and poetry, presents Leg. Silv. in 23 rhyming triplets, beginning with: "Denariis triginta Deum vendit Galilaeus, quos et apostolicus describit Bartholomaeus, unde prius veniant, quis fabricavit eos." Where Godfrey found Leg. Silv. is unclear. He claimed the source was a sermon in Hebrew of the apostle Bartholomew to the Armenians; but the legend does not appear in any known work attributed to Bartholomew. ${ }^{4}$

${ }^{2}$ For a survey of the Western versions of Leg. Silv. see George Francis Hill, "The Thirty Pieces of Silver" (Archaeologica 59 [1905], 235-54) (repr. in idem, The Medallic Portraits of Christ: The False Shekels: The Thirty Pieces of Silver [Oxford: Clarendon Press, 1920], 91-116), and David Hook, "The Legend of the Thirty Pieces of Silver," in The Medieval Mind: Hispanic Studies in Honour of Alan Deyermond, ed. Ian R. MacPherson, and Ralph J. Penny (London: Tamesis, 1997), 205-208. For other scholarship (primarily summary) on Western traditions about the thirty silver pieces see: Rudolph A. Hofmann, Das Leben Jesu nach den Apokryphen im Zusammenhang aus den Quellen erzählt und wissenschaftlich untersucht (Leipzig: Friedrich Voigt, 1851), 333; Wilhelm Creizenach, Judas Ischarioth in Legende und Sage des Mittelalters, Separatabdruck aus den Beiträgen zur Geschichte der Deutschen Sprache und Literatur, Band II, Heft 2 (Halle, Lippert'sche Buchhandlung, 1875); and Erica Reiner, "Thirty Pieces of Silver" (JAOS 88.1 [1968], 18690).

${ }^{3}$ Godfrey of Viterbo, Pantheon, sive Vniversitatis Libri, qui Chronici appellantur, xx (Basel: ex officina Iocabi Parci, 1559); also found in Edélestand du Méril, ed., Poésies populaires latines du Moyen Age (Paris: Firmin Didot \& A. Franck, 1847). Hill provides a free translation in "Thirty Pieces," 91-93.

4 Paolo Cherchi ("A Legend from St Bartholomew's Gospel in the Twelfth Century" [RB 91 (1984), 212-18]) argues that the lost Gospel of 
The second Western writer who drew upon the text is Ludolph of Suchem. He journeyed to the Holy Land in 1336-1341 and wrote about his trip in De Itinere Terrae Sanctae, published between 1350 and $1361 .{ }^{5}$ The chapter on the coins (ch. 39) is said to derive from a text called the "History of the Kings of the East." Perhaps this same text was read by the pilgrim Felix Fabri of Nuremberg at the end of the fifteenth century; he says he read the tale in a "certain long and wordy history." 6

The third and final Western writer is John of Hildesheim who incorporated Leg. Silv. in his Historia Trium Regum (chs. 28-29).7 John was a Carmelite friar who composed his text some time between 1364 and 1375 (the year of his death). The Historia was inspired by the translation of the bodies of the three Magi to Cologne in 1164. Three fingers from the bodies were given to the cathedral of Hildesheim. There grew a desire for a complete legend of the three national saints, and this need was met by John. In

Bartholomew may have incorporated the story of the coins, and that Godfrey may have used a Latin version of this text. Hill thinks Godfrey may have drawn upon a Latin translation of some legend of Armenian origin ("Thirty Pieces," 237).

${ }^{5}$ See Hill, "Thirty Pieces," 96-97, which includes a brief summary of Ludolph's version of the tale. For an edition of the text see Ferdinand Deycks, ed., Ludolphi, rectoris ecclesiae parochilais in Suchem, De itnere terrae Sanctae Liber, Bibliothek des Litterarischen Vereins in Stuttgart 25 (Stuttgart: Literarischer Verein, 1851) and Aubrey Stewart, trans., Ludolph von Suchem's Description of the Holy Land, and of the Way Thither, Written in the Year AD 1350, Palestine Pilgrims' Text Society 12 (London: Palestine Pilgrims' Text Society, 1895).

${ }^{6}$ Hill, "Thirty Pieces," p. 100. See further Cunradus D. Hassler, ed., Evagatorium in Terrae Sanctae, Arabia et Egypti peregrinationem, Fratris Felicis Fabri, vol. 1 (Stuttgart: Sumptibus Societatis Litterariae, 1843), 246. For an English translation see Aubrey Stewart, Book of the Wanderings of Brother Felix Fabri, Palestine Pilgrims' Text Society 7-10 (London: 24 Hanover Square W., 1893-1896); for the Leg. Silv. section see vol. 1.2, 532-33.

${ }^{7}$ See Hill, "Thirty Pieces," 97-99. The first modern edition was made by Ernst Köpke, Mittheilungen aus den Handschriften der Ritter-Akademie zu Brandenburg A.H., vol. 1: Johannes von Hildesheim (Brandenburg: G. Matthes, 1878). The edition is reproduced, along with variants from other manuscripts, in Carl Horstman, ed., The Three Kings of Cologne: An Early English Translation of the 'Historia Trium Regum' by John of Hildesheim, EETS, Old Series 85 (London: Oxford University Press, 1886). Horstman also provides details of John's life and works (Ibid., xii-xvi). 
chapter four, John lists his sources as "books written in Hebrew and Chaldee of the life and deeds, and all matters of the 3 kings"; however, as Horstman states, these are "no doubt, a mere fiction, or perhaps mention was made of them in his real sources." 8 The Historia was quite popular in John's day and spawned translations into English and German. ${ }^{9}$ It fell into some obscurity during the Reformation but was rediscovered in the nineteenth century.

Leg. Silv. is also preserved in several Latin manuscripts. A fifteenth-century manuscript from Italy (British Library, 22553, fol. $144 \mathrm{v}$ ) and a contemporary one from Germany (British Library, Add. 34139 , fol. 87 r; 1492 or early $16^{\text {th }}$ cent. $)^{10}$ contain versions of the text distinct from the one known to the three Western writers. ${ }^{11}$ Also of note are a handful of Latin manuscripts that have yet to be evaluated. Included in these are British Library, Add. 34276 (fol. $33^{\mathrm{v}}, 15^{\text {th }}$ cent.), ${ }^{12}$ which seems to be an abbreviation of John of Hildesheim's version; Halle, Universitäts- und Landesbibliothek, Stolb.-Wernig $\mathrm{Za} 69 \mathrm{~m}$ (fol. 23v-24v , $15^{\text {th }}$ cent.); ${ }^{13}$ Bibliothèque nationale, Manuscrits latins des nouvelles acquisitions 543 (fol. 112 ${ }^{\mathrm{v}}-113^{\mathrm{r}}$;

${ }^{8}$ Ibid, xiv.

${ }^{9}$ See Horstman, Three Kings of Cologne, for an edition and discussion of the Old English version, which is an abbreviation of the Historia Trium Regum made around 1400. A German translation was made as early as 1389. For a broader discussion of the manuscript tradition of the English and German translations see Max Behland, Die Dreikönigslegende des Johannes von Hildesheim (Munich: W. Fink, 1968) and Sylvia C. Harris, "German translations of the Historia Trium Regum by Johannes de Hildesheim" (Modern Language Review 53 [1958], 364-73); idem, "The Historia Trium Regum and the Mediaeval Legend of the Magi in Germany" (Medium aevum 28 [1959], 23-30).

${ }^{10}$ Trustees of the British Museum, Catalogue of the Additions to the Manuscripts of the British Museum 1888-1893 (London: British Museum, 1894), 210-11.

${ }^{11}$ See Hill, “Thirty Pieces," 101.

${ }^{12}$ Ibid., 282-83.

${ }^{13}$ Renate Chipke and Kurt Heydeck, Handschriftencensus der kleineren Sammlungen in den östlichen Bundesländern Deutschlands: Bestandsaufnabme der ehemaligen Arbeitsstelle "Zentralinventar Mittelalterlicher Handschriften bis 1500 in den Sammlungen der DDR" (ZIH) (Wiesbaden: Harrassowitz, 2000), 310. This manuscript has not been discussed in previous scholarship. 
14th cent.); 14 and Vienna, Ms No. 1948 (no fol. nos. provided; 1332). ${ }^{15}$ It is notable that all the versions of Leg. Silv. named here appear as independent self-contained works and not as a part of either Pantheon, De Itinere Terrae Sanctae, or Historia Trium Regum. The Vienna manuscript, however, seems to be identical to Godfrey's text or its source, as are several versions of Hispanic provenance. ${ }^{16}$

Despite the exotic statements of origin for Leg. Silv. by Godfrey, Ludolphe, and John, likely the text became available to the writers in Latin, perhaps as a translation from a lost Greek original. All three published versions differ in many places, though Harris saw enough significant correspondences between them to conclude that John's account was dependant on Ludolph's and supplemented by details from Godfrey. ${ }^{17}$ Hook, however, suggests that John may have used a text similar to Godfrey's source. ${ }^{18}$

The Western form of the text has several identifying features. The silver pieces are said to derive from a collection of gold coins created by Terah for Ninus, king of the Assyrians; they are used by the Ishmaelites to purchase Joseph; the Ishmaelites pass the coins on to the Queen of Sheba; after Nebuchadnezzar they go to Saba (Godfrey) or Arabia (John) or Godolia (Ludolph), and then to Nubia (Ludolph, John); there is no mention of the Persians, nor of Edessa and Abgar; they pass on from the Nubians or the Magi (via Saba in Godfrey) to the Christ child; from there they are lost in Egypt, where they are found and returned to Christ. Finally, Ludolph and John end stating that the coins were dispersed after the death of Judas. Two of the writers (Godfrey and Ludolph) take

${ }^{14}$ Société de l'école des Chartres, Bibliothèque de l'École des chartres. Revue d'érudition consacrée specialement a l'étude du moyen age, vol. 53 (Paris: Libraire d'Alphonse Picard, 1892), 341. This manuscript has not been discussed in previous scholarship.

15 Academia Caesarea Vindobonensis, Tabulae codicum manu scriptorum praeter Graecos et orientales in Bibliotheca palatina Vindobonensi asservatorum, Volumen 1, Cod. 1-2000 (Vienna: Gerold, 1864), 303. The catalog cites the incipit and the last verse: "In folio numero non signato inter thecam et folia signata carmen 67 versuum de triginta argenteis, quibus Christus venditus est. Incip. 'Denariis triginta deum vendit galilenus. . ' Expl.: 'Cuius sunt vota et non dicere facta remota."' These are nearly identical to Godfrey's version in du Méril's edition.

${ }^{16}$ See Hook, "Legend," particularly 209-16.

${ }^{17}$ Harris, "German translations," 29.

${ }^{18}$ Hook, "Legend," 208. 
great pains to explain how the gold pieces of Terah became the silver pieces of Judas. The discrepancy may derive from the blending of two traditions: the original silver pieces of Leg. Silv. with the gold pieces said to have been given to the Christ child by Melchior, one of the Persian Magi, and which were coined by Terah, paid to the Queen of Sheba by Joseph, and given by the Queen to Solomon. ${ }^{19}$ Gold coins as part of the gifts of the Magi are mentioned also in the Gospel of Psendo-Matthew ch. 16.

This notion of the dispersion of the coins serves as back story to the existence of "Judas-penny" relics. ${ }^{20}$ More than thirty of these coins are recorded in various sources; some of them are still extant. The references to the coins go back to as early as the fifteenth century and they seem to have been dispersed in France, Italy, Bologna, Rhodes, and Russia. Not one of them, of course, was of the kind in circulation at the time of Jesus. ${ }^{21}$

\section{THE LEgEND IN THE SYRIAC TRADITION}

Scholars' first look at the Syriac version of Leg. Silv. came in 1866 with the publication of Solomon of Basra's Book of the Bee.22 Solomon was bishop of Basra (in modern-day Iraq) beginning around 1222. His book is a collection of theological and historical texts covering events and figures from creation to the final day of resurrection. He includes the story of the silver pieces in a chapter (ch. 44 in Budge's edition) that relates the origins of a variety of artifacts from the Passion of Christ, including his tomb, the purple cloak, and the cross. The first critical edition of the Book of the Bee, made by J. M. Schoenfelder, included a Latin translation of the text based on a single manuscript from Munich (Ms C below). Twenty years later E. A. Wallis Budge contributed a more comprehensive

${ }^{19}$ See Ernest A. W. Budge, The Book of the Bee: The Syriac Text Edited from the Manuscripts in London, Oxford, Munich, with an English Translation, Anecdota Oxoniensia, Semitic Series 1 part 2 (Oxford: Clarendon Press, 1886), 95 n. 5.

${ }^{20}$ For a detailed discussion of the coins see Fernand de Mély, "Les Deniers de Judas dans la Tradition du Moyen Âge" (Revue Numismatique 4.3 [1899], 500-9, summarized and updated in Hill, "Thirty Pieces," 10316.

${ }^{21}$ Hill, "Thirty Pieces," 103.

22 J. M. Schoenfelder, Salomonis, episcope Bassorensis, liber apis, syriacum arabicumque textum latine (Bamberg: O. Reindl, 1866). 
edition, in Syriac and English, incorporating readings from two additional Syriac manuscripts and another in Garšūnì:

A London, Royal Asiatic Society, Syr. 1, paper, 8 x 5 $3 / 4$ in., 188 fols., East Syriac, 1559; fol. 26r-92v.23

B London, British Library, Add. 25875, paper, $87 / 8$ × 6 1/8 in., 362 fols., East Syriac, 1709/1710: fol. 81v-157v. ${ }^{24}$

C Munich, Bayerische Staatsbibliothek, Cod. Syr. 7, paper, 12 1/8 x 8 1/4 in., 146 fols., East Syriac (right column in Syriac, left in Garšūnī), end 17th/beginning $18^{\text {th }}$ cent. $^{25}$

D Oxford, Bodleian Library, 141 (formerly Poc. 89), paper, 8 5/8 x 6 1/4 in., 405 leaves, Garšūnī, 1584: fol. 81-217.26

At the time, Budge characterized Schoenfelder's text as "faulty in many places," and promised to deliver a better edition. ${ }^{27} \mathrm{He}$ also mentioned the existence of several additional manuscripts of the text: 28

Vatican, Syr. 176, paper, 119 fols.(?), East Syriac, 17th cent.: fol. $42-126.29$

${ }^{23}$ This is the same manuscript used for Budge's edition of the Syriac Life of Mary: Ernest A. W. Budge, The History of the Blessed Virgin Mary and the History of the Likeness of Christ, 2 vols., (London: Luzac \& Co., 1899). Full manuscript details are supplied by William Wright, Apocryphal Acts of the Apostles, Edited from Syriac manuscripts in the British Museum and Other Libraries, vol. 1: The Syriac Texts (London: Williams and Norgate, 1871), xxii.

${ }^{24}$ William Wright, Catalogue of the Syriac Manuscripts in the British Museum Acquired since the Year 1838, Part 3 (London: Longmans \& Co., 1872), 1064-69.

${ }^{25}$ Joseph Aumer, Verzeichniß der orientalischen Handschriften der K. Hofund Staatsbibliothek in München, mit Ausschluß der bebraeischen, arabischen und persischen (1875; Wiesbaden: Otto Harrassowitz, 1970), 114-15.

${ }^{26}$ Robert Payne Smith, Catalogi Codicum Manuscriptorum Bibliothecae Bodleianae, Pars sexta (Oxford: Bodleian Library, 1864), 452-58.

${ }^{27}$ Budge, Book of the Bee, iii.

${ }^{28}$ Ibid., ix.

29 Stefano E. Assemani, Bibliothecae Apostolicae Vaticane Codicum Manuscriptorum catalogus, vol. 2: Codices Chaldaicos sive Syriacos (1758; Paris: Maissoneuve, 1926), 363-67. Assemani's information on the manuscript is 
Vatican, Syr. 177, paper, 83 fols., East Syriac, n.d.: fol. 1-83.30

Paris, Bibliothèque nationale, Fonds Syriaque 232, paper, 592 fols., Garšunini, 17th cent.: fol. 1-81 (said to be a copy of D but missing the beginning and end, and full of lacunae). ${ }^{31}$

Paris, Bibliothèque nationale, Fonds Syriaque 368, paper, $210 \mathrm{x}$ $150 \mathrm{~mm}$., East Syriac, 16 ${ }^{\text {th }}$ cent.: fol. 1-16 and 18-41 (missing the beginning and end, and full of lacunae). ${ }^{32}$

And since Budge's day, more manuscripts have come to light:

London, British Library, Or. 4526, paper, 8 285 fols., 1727: fol. $54^{\mathrm{r}}-155^{\mathrm{r}}$. $^{33}$

London, British Library, Or. 5281, paper, $4^{\circ}, 146$ fols., $18^{\text {th }}$ cent. $^{34}$

Cambridge, University Library, Add. 2815, paper, 9 x 6 3/4 in., 91 fols., 1887.35

Birmingham, Mingana, Syr. 93, paper, 221 x 162 mm, 101 fols., 1886.36

contradictory: he lists the folio count at 119, but the Book of the Bee's placement in the manuscript as running to fol. 126 and discusses the presence of some librarian's notes on fol. 128 .

${ }^{30}$ Ibid., 367.

${ }^{31}$ Hermann Zotenberg, Catalogues des manuscrits syriaques et sabéens (mandaïtes) de la Bibliothèque nationale (Paris: Imprimerie nationale, 1874), $177-81$.

${ }^{32}$ Françoise Briquel-Chatonnet, Manuscrits syriaques de la Bibliothèque nationale de France (nos 356-435, entrés depuis 1911), de la bibliothèque Méjanes d'Aix-en-Provence, de la bibliothèque municipale de Lyon et de la bibliothèque nationale et universitaire de Strasbourg (Paris: Bibliothèque nationale, 1997), 4041.

${ }^{33}$ George Margoliouth, Descriptive List of Syriac and Karshuni MSS. in the British Museum Acquired since 1873 (London: Longmans \& Co., 1899), 46-47. This manuscript, like Urmia 38 below, is closely related to Royal Asiatic Society, Syr. 1 (Budge's Ms A) - the three contain virtually all the same texts and in the same order.

${ }^{34}$ Ibid., 49. Folio numbering not provided.

35 William Wright, Catalogue of the Syriac Manuscripts in the Library of the University of Cambridge, vol. 2 (London: C. J. Clay and Sons, 1901), 658-59.

36 Alphonse Mingana, Catalogue of the Mingana Collection of Manuscripts, vol. 1 (Cambridge: W. Heffer \& Sons, Ltd., 1933), 233. 
Yale, Beinecke Library, Syr. 4, paper, 211/2 x 151/2 in., 134 fols., 1687.37

Teheran, Neesan 28 (18 th cent.?). ${ }^{38}$

Urmia 38, paper, 8 573 fol. (or pages?), 1885: no fol. numbers provided. ${ }^{39}$

Clearly more work could be done to establish the text of the Book of the Bee and thus of the version of Leg. Silv. preserved within it. The edition of the Eastern text of Leg. Silv. offered below incorporates only the manuscript readings provided by Budge.

In the years between Schoenfelder's and Budge's editions there appeared Paul de Lagarde's collection Praetermissorum libri duo, which includes an editon of Leg. Silv. ${ }^{40}$ Lagarde said little about the sources he used for his texts, but it is now clear that for Leg. Silv. he used British Library, Syriac 9 (Ms M, discussed below). ${ }^{41}$ Along with Leg. Silv. and an edition of Elias of Nisibis' Kitäb at-tarğumān in

${ }^{37}$ See James T. Clemons, "A Checklist of Syriac Manuscripts in the United States and Canada" (OCP 32 [1966], 487, No. 247); and Alain Desreumaux, Répertoire des bibliothèques et des catalogues de manuscrits syriaques, Documents, études et répertoires publiés par l'Institut de recherché et d'histoire des texts (Paris: Éditions du CNR, 1991), 199, no. 611.

38 The existence of this manuscript, as yet uncataloged and unevaluated, was made known to us by Alain Desreumaux. For more on the manuscripts of Teheran see Desreumaux, Répertoire, 237.

${ }^{39}$ Kashisha Oshana Sarau and John H. Shedd, Catalogue of Syriac Manuscripts in the Library of the Museum Association of Oroomiab College (Urmiah: Library of the Museum Association of Oroomiah College, 1898), 10. This manuscript is now lost.

40 Paul de Lagarde, Praetermissorum libri duo (Göttingen: Officina Academica Dieterichiana, 1879).

41 In Pratermissorum, de Lagarde lists three sources: "g codex gothanus 1091" (current designation Universitäts- und Forschungsbibliothek Erfurt / Gotha Ms. orient. $A g$ 79; for a description of this manuscript, see Wilhelm Pertsch, Die orientalischen Handschriften der Herzoglichen Bibliothek zu Gotha [Gotha: Friedr. Andr. Perthes, 1893], 58-59), "h codex londoniensis" (our Ms M), and "r," which is Thesaurus arabicosyro-latinus by Tommaso Obicino (aka Tommaso de Navaria [Rome: Sac. Congregationis de propag. Fide, 1636]). Lagarde's "h codex londoniensis" is confirmed as BLSyr. 9 by the description of the manuscript in Giuseppe Furlani, "Il manoscritto siriaco 9 dell'India Office" (RSO 10 [1923-1925], 315-20). 
Arabic and Hebrew script, Lagarde's book also contains various other lexicographical material taken from $\mathrm{M}^{42}$ and Bar Hebraeus's commentary on the Psalms, all presented in Hebrew script. Thus, the first publication of Leg. Silv. as a distinct text came over a century ago, but it made little to no impact on scholarship on the text.

The entire range of known Syriac manuscripts for Leg. Silv, either as a distinct text or incorporated into the Book of the Bee, falls into two recensions. The Western recension comprises five Serto manuscripts. The Eastern recension comprises four East Syriac manuscripts and the Book of the Bee. The Garšunin manuscripts contain features from both recensions and have undergone independent development. All of the manuscripts used in the present study are described below.

\subsection{Manuscripts of the Western Recension ${ }^{43}$}

A Paris, Bibliothèque nationale, Fonds Syriaque 197, 263 fols., Serto, 16 th cent.: fol. 93r-94v.44

This manuscript, copied by a scribe named James, is a large collection of homilies, poetry and extracts from lives of saints in Syriac and Arabic (Garšūnī). Notable works contained herein include the collected poems of Bar Hebraeus (fol. 118v-226v) and a number of homilies by Jacob of Sarug and Ephrem the Syrian. Manuscript A was selected as the base manuscript for the recension as it appears to suffer from the least amount of errors and omissions (note the two observable grammatical errors, shared with $\mathrm{B}$, in 1.14 and 53 , and three idiosyncratic readings in $1.7,28$, and 42). This manuscript is related to $B$ (see below).

B Paris, Bibliothèque nationale, Fonds Syriaque 215, 86 fols., Serto, 17th cent.: fol. $82^{\mathrm{v}-83^{\mathrm{v}} .45}$

42 An excerpt from what Furlani calls "Alcuni versi I spiegazioni di parole" (BLSyr. 9, fol. 441-444), an excerpt from "Spiegazioni di parole" (BLSyr. 9, fol. 189v-191v), and a fragment taken from BLSyr. 9, fol. 196.

${ }^{43}$ Many of the manuscripts described below, including those of the Eastern recension and the Garšūnī versions, are listed in Florence Jullien, "La légende des Trente pièces d'argent de Judas et le roi Abgar" (Apocrypha 24 [2013], 207-20).

${ }^{44}$ Zotenberg, Manuscrits orientaux, 144-47. 
Much of the contents of this thin volume are identical to those of A:

\section{Title}

Collected poems of Bar Hebraeus

A poem by David, son of Paul, on the Syriac alphabet
A

$150^{\mathrm{v}-226^{\mathrm{v}}}$

$227^{\mathrm{r}-235^{\mathrm{v}}}$

$15^{\circ}$

\section{Zotenberg B}

No.

$14^{\circ} \mathrm{f}-\mathrm{gg}$

$$
\begin{array}{lll} 
& \text { No. } 56^{\mathrm{r}} & 2^{\circ}
\end{array}
$$

$2^{\circ}$

111 Pythagorean

symbolic maxims

taken from a letter

of Theodosius, the

patriarch of

Antiochia

A homily on the

solitary life of

hermits

A homily on poverty and alms

Another homily

on hermits,

different from the

previous one

Leg. Silv. $236^{\mathrm{r}-244^{v}} \quad 16^{\circ}$

$60^{\mathrm{r}-62^{\mathrm{v}}} \quad 4^{\circ}$

$245^{r}-258^{r}$

$17^{\circ}$

$63^{r}-68^{r} \quad 5^{\circ}$

$259^{\mathrm{r}}-263^{\mathrm{r}} \quad 18^{\circ}$

$68^{\mathrm{v}-69^{\mathrm{v}}} \quad 6^{\circ}$

$105^{\mathrm{r}}-118^{\mathrm{r}}$

$13^{\circ}$

$70^{\mathrm{r}}-75^{\mathrm{r}} \quad 7^{\circ}$

$93^{\mathrm{r}-94^{\mathrm{v}}}$

$11^{\circ}$

$82^{\mathrm{v}-}-83^{\mathrm{v}} \quad 11^{\circ}$

Along with a third homily on the hermit life $\left(8^{\circ}\right.$, fol. $\left.75^{\mathrm{v}-79^{\mathrm{v}}}\right)$, this manuscript further contains a list of monastic rules in Arabic (Garšūni, $1^{\circ}$, fol. 1-8r) relating to discipline, two alphabetical poems $\left(9^{\circ}\right.$ and $10^{\circ}$, fol. $80^{\mathrm{r}-82^{\mathrm{r}}}$ ) and a collection of letters written by a priest to a deacon, a metropolitan and a bishop $\left(12^{\circ}\right.$, fol. $\left.83^{\mathrm{v}}-85\right)$. The text of $\mathrm{B}$ follows close that of $\mathrm{A}$, aside from two minor departures (1. 20,42) and a case of dittography (1. 24-25), perhaps due to homoeoteleuton. The presence of this error, along with the

${ }^{45}$ Ibid., 166. 
date of the two manuscripts and the order of the texts, suggests that B is a copy of A or a very similar manuscript.

C Birmingham, Mingana Syr. 480, 418 x 261 mm., 428 fols., Serto, 1712/13: fol. 241v-242r ${ }^{\mathrm{r}}{ }^{\mathrm{C}}$

Mingana describes $\mathrm{C}$ as "a handsome and sumptuous MS. containing the New Testament and many other treatises." 47 Included among these treatises are works by Jacob of Edessa, Ephrem, John of Saba, and Philoxenos of Mabbug. The bulk of the manuscript is devoted to the four gospels in the Harklean Version (fol. $33^{v}-303^{v}$ ), with the text in one column and commentary in the other. Several maps and diagrams follow the gospels. Then we see the Acts of the Apostles according to the Peshitta Version (310v311v), the Catholic Epistles (fol. 334v-344r), the Epistles of Clement (344r-351r), and the Pauline Epistles (351v-397r). Leg. Silv. is found near the start of the Gospel of John (John begins at fol. 234v). The colophon $(427 \mathrm{v}-428 \mathrm{v})$ provides the date of the manuscript and its place of origin in the Church of the Forty Martyrs of Sebaste in the town of Mardin. It reveals also that the manuscript was copied from another created for the Metropolitan of Aleppo, Dionysius Shukr-Allah from Mardin. The manuscript is very similar to A and B, with two major differences: an extra word in 1.22 ("and sat down") which is found also in the Eastern recension, and a repeated word (due to dittography) in 1. 39. C features several other unique readings (1. 1 of the title and in $1.16,33,42,45,48-49,50$, and 54), and shares a number of variants with manuscripts D and E (see 1. 1, 2, 9, 14, 20, 31, 32, 38, 53, and 56), though none of these are significant enough to indicate a direct relationship between $\mathrm{C}$ and $\mathrm{DE}$.

D Birmingham, Mingana Syr. 71, 218 x 155 mm., 154 fols., Serto, ca. 1600: fol. $134^{\mathrm{v}}-136^{\mathrm{v}}{ }^{48}$

This undated manuscript contains various lives, treatises, notes, prayers, and brief stories, some of which are incomplete. Some

46 Mingana, Catalogue of the Mingana Collection, 863-82 (here listed incorrectly as fol. $240^{\mathrm{v}}-241^{\mathrm{r}}$ ).

${ }^{47}$ Ibid., 863.

${ }^{48}$ Mingana, Catalogue of the Mingana Collection, 180-88. 
pages have been bound out of order. Mingana describes it as a collection "from different MSS., written by two hands and put together by an early binder." 49 There are a number of errors in the manuscript (see 1. 18, 20, 25, 48, 49) that have been corrected likely by the scribe himself, and several unique readings: 1.1 of the title (perhaps shared with C), the addition of "village" in 1.3 (also found in the East Syrian recension), and other variants in 7, 15, 25, and 43). The manuscript is related to $\mathrm{E}$ (see further below).

E Birmingham, Mingana Syr. 369, 255 x 176 mm., 159 fols., Serto, ca. 1480: fol. 130r-131r. 50

This manuscript, the earliest we have of the text, is a collection of Syriac and Garšūnī texts originating from different manuscripts and in several different hands. A number of the texts are shared with D:

E D

1. Memra on the parrot which sang the trisagion in Antioch

2. Treatise on the Syrian authors known as Isaac

3. Collection of pious anecdotes

4. History of Rome by Diocles Peparethius

5. Question by an Egyptian monk to old hermits

6. A story on the faithfulness of a dog

7. Astronomical and physical notes by Dionysus

8. How to hold a controversy with a Nestorian

9. Ephrem on the Trinity

10. Story of a demon who repented
$\mathrm{F}\left(24^{\mathrm{v}}-29^{\mathrm{v}}\right) \quad \mathrm{K}\left(73^{\mathrm{v}}-83^{\mathrm{r}}\right)$

G (29v) L $\left(83^{v-84 r)}\right.$

$\mathrm{J}\left(34^{\mathrm{r}-40 \mathrm{v}}\right) \quad \mathrm{N}\left(88^{\mathrm{r}-101 \mathrm{r}}\right)$

$\mathrm{K}\left(40^{\mathrm{v}}-43^{\mathrm{v}}\right) \quad \mathrm{O}\left(101^{\mathrm{r}}-106^{\mathrm{v}}\right)$

$\mathrm{L}\left(43^{\mathrm{v}-44 \mathrm{r})} \quad \mathrm{P}\left(106^{\mathrm{v}}-107 \mathrm{v}\right)\right.$

M (44r-44v) Q (106r-107v)

$\mathrm{N}\left(44^{\mathrm{v}}-46^{\mathrm{r}}\right) \quad \mathrm{R}\left(108^{\mathrm{v}}-112^{\mathrm{r}}\right)$

$\mathrm{O}\left(46^{\mathrm{r}-47 \mathrm{r})} \quad \mathrm{S}\left(112^{\left.\mathrm{r}-113^{\mathrm{v}}\right)}\right.\right.$

$\mathrm{P}\left(47^{\mathrm{r}}\right) \quad \mathrm{T}\left(113^{\left.\mathrm{r}-114^{\mathrm{r}}\right)}\right.$

Q (47v-50r) U (114r-118v $)^{51}$

\footnotetext{
${ }^{49}$ Ibid., 181.

${ }^{50}$ Ibid., 669-80.

${ }^{51}$ There is no item $\mathrm{V}$.
} 


\begin{tabular}{|c|c|c|}
\hline 11. Prayer before a Sultan & $\mathrm{R}\left(50^{\mathrm{r}-50 v}\right)$ & $\mathrm{W}\left(118^{\mathrm{v}}-119^{\mathrm{v}}\right)$ \\
\hline $\begin{array}{l}\text { 12. Order of prayers over a dying } \\
\text { man }\end{array}$ & aa $\left(77^{\mathrm{r}}-79^{\mathrm{v}}\right)$ & $\mathrm{X}\left(119^{\mathrm{v}}-128^{\mathrm{v}}\right)$ \\
\hline 13. Sayings of the desert fathers & $\operatorname{gg}\left(96^{r_{-}} 97 v\right)$ & $Y\left(128^{v-130 v}\right)$ \\
\hline $\begin{array}{l}\text { 14. Acrostic admonitions by } \\
\text { Ephrem }\end{array}$ & hh (98) & $\mathrm{Z}\left(130^{\mathrm{v}}-132^{\mathrm{r}}\right)$ \\
\hline $\begin{array}{l}\text { 15. Treatise on six Syriac letters } \\
\text { with two sounds }\end{array}$ & $\mathrm{jj}\left(115^{\mathrm{r}}-116^{\mathrm{v}}\right)$ & aa $\left(132^{\mathrm{v}}-13\right.$ \\
\hline 16. Leg. Silv. & $11\left(130^{\mathrm{r}}-131^{\mathrm{r}}\right)$ & bb $(134 v-13 c$ \\
\hline
\end{tabular}

The shared material appears in a variety of hands in E, with Leg. Silv. written by a certain Basil the door-keeper of a church in the Monastery of Za'farān in $1481.5^{52}$ The precise nature of the relationship between manuscripts $\mathrm{D}$ and $\mathrm{E}$ is uncertain. Both contain a host of shared variants, including one agreement with the Eastern recension in 1.39 (note also "king of the Persians" in 1. 7); and they share several omissions (see 1. 2-3 of the title; 1. 7-8, 50, and 57-58). E has three unique readings in $1.15,44$, and 51 . The weight of this evidence would suggest that $\mathrm{E}$, or a very similar manuscript, is the source of D. Other noteworthy texts in the two manuscripts are portions of Apoc. Pet. (=Book of the Rolls) in Garšūni (fol. 30r-32r), ${ }^{53}$ the Martyrdom of Pilate (fol. 117r-130r), ${ }^{54}$ and the Life of John the Baptist by Serapion (fol. 142-149v). ${ }^{55}$

\subsection{Manuscripts of the Eastern Recension}

The Eastern recension is available as a distinct text in three manuscripts and is incorporated also into Solomon of Basra's Book of the Bee. All of the Eastern witnesses feature the same lengthy title and the mention of the prophecy of Zarathustra (1. 16; though this

${ }^{52}$ Basil is responsible also for items B, D, E, F, G, H, I, Y, Z, kk, mm, and nn. J to $\mathrm{P}$ are by another hand, $\mathrm{Q}$ and $\mathrm{R}$ by another, and aa to hh and ji by others.

53 See Alphonse Mingana, Woodbrooke Studies: Christian Documents in Syriac, Arabic, and Garshuni, 3 vols. (Cambridge: Cambridge University Press, 1927-1931), 3:93-450.

${ }^{54}$ See Mingana, Woodbrooke Studies, 2:241-332 but based on Mingana Syr. 127 and Syr. 355 (both in Garšūnī) and a Paris manuscript (Arab. 152).

55 See Mingana, Woodbrooke Studies, 1:138-287. The edition is based on Mingana Syr. 22 (discussed under the Garšūnī manuscripts below) and Syr. 183. 
is not found in P). Also, they lack a number of readings found in the Western recension: part of the dialogue between the shepherds and the merchants (1. 39-41, 42-43), the statement that Jesus knew the secrets of the Robe and the pieces (1. 48-49), the command to Judas to deliver Jesus (1.51), and the depositing of the pieces in the fountain along with the staff of Moses (1. 55-57).

M London, British Library, Syriac 9 (formerly India Office Syriac 9), octavo, 444 fols., East Syriac, 1712/13: fol. 242r-243r.56

With the exception of fols. 59v to $193^{\mathrm{v}}$, the manuscript is divided into two columns. Titles and conclusions are written in red ink; the rest of the text is in black ink and fully vocalized using the eastern vocalization system. Furlani identifies in the manuscript 84 separate works of various types, mostly short treatises on philosophy and linguistic matters. Fol. $1^{\mathrm{r}}$ to $44^{\mathrm{r}}$ contain a version of Kitäb at-tarğumàn-i.e., "Book of the Translator," an Arabic-Syriac dictionary organized by semantic fields compiled by Elias of Nisibis (d. 1049). This very manuscript was used by Paul de Lagarde for his edition of both Kitäb at-tarğumān and Leg. Silv. ${ }^{57} \mathrm{M}$ appears to be the best manuscript of the Eastern recension, with

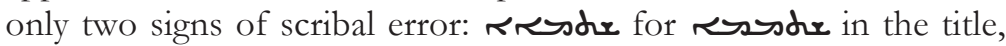
and a single word added super linea in 1. 26; note also the unique reading in 1. 41-42. The manuscript is also the only witness in the Eastern recension to a reading attested in the Western recension (1. 35).

N Berlin, Staatsbibliothek zu Berlin, Syr. 74 (formerly Sachau 9), 208 x 140 mm., 128 fols., East Syriac, 1695: fol. 20v-22r.58

Sachau describes the manuscript as "Sammelband, enthaltend: Theile der Schatzhöhle und des Buches der Biene; Apokryphe Apostel-Acten; eine Josephs-Geschichte von Basilius dem Grossen; Heiligen-Legenden." ${ }^{59}$ However, the only portions identifiable as parts of the Book of the Bee are Leg. Silv. (fol. 20v-22r) and the

${ }^{56}$ Furlani, "Il manoscritto siriaco 9."

${ }^{57}$ Lagarde, Praetermissorum Libri Duo. Leg Silv. apppears at 94-96.

${ }^{58}$ Eduard Sachau, Verzeichniss der syrischen Handscbriften der Königlichen Bibliothek. Erste Abtheilung (Berlin: A. Asher \& Co., 1899), 281-88.

${ }^{59}$ Ibid., 281. 
introduction (fol. $22^{r}-24 v$ ). The manuscript is related to $O$ (see below), but suffers from fewer errors (see 1. 16, 40, 48, 49; for readings unique to $\mathrm{N}$ see titulus 1.1 and $4,1.5,25-26,40,46$, and 47).

O Paris, Bibliothèque nationale, Fonds Syriaque 309, 240 x 160 mm., 344 fols., East Syriac, 1869: fol. 51v-53v 60

This relatively modern volume-written by a 13-year old student named Elias from Alqosh, Iraq, and completed in July 1869-contains 21 separate works. With the exception of the first one-Songs for the Feast of the Resurrection (fol. $1^{\mathrm{v}}-10^{\mathrm{r}}$ ) - these are lives of saints and other legends. The manuscript is related to $\mathrm{N}$, though perhaps not directly. $\mathrm{N}$ and $\mathrm{O}$ share the following texts:

\begin{tabular}{|c|c|c|}
\hline & $\mathbf{N}$ & $\mathbf{O}$ \\
\hline Leg. Silv. & $20^{\mathrm{v}}-22^{\mathrm{r}}\left(4^{\mathrm{o}}\right)$ & $51^{\mathrm{v}}-53^{\mathrm{v}}\left(3^{\circ}\right)$ \\
\hline $\begin{array}{l}\text { Acts of Andrew and } \\
\text { Mathaias }\end{array}$ & $82^{\mathrm{v}}-91^{\mathrm{r}}\left(12^{\circ}\right)$ & $53^{\mathrm{v}}-66^{\mathrm{r}}\left(4^{\circ}\right)$ \\
\hline $\begin{array}{l}\text { Legend of John, the son } \\
\text { of the king of Rome }\end{array}$ & $121^{\mathrm{r}}-128^{\mathrm{v}}\left(15^{\circ}\right)$ & $77^{\mathrm{v}}-91^{\mathrm{v}}\left(6^{\circ}\right)$ \\
\hline
\end{tabular}

The two manuscripts share a number of readings within Leg. Silv. (see particularly 1. 8-9, 24) and several significant omissions (1. 7-8, $12-13,9-12$, and 35). The title is now illegible, as are four lines of text at the start of fol. 52v (though these lines are not part of Leg. Silv.). O also has some particular features: two words are added super linea (1. 41, 46; the latter word is lacking in $\mathrm{N}$ ); there is a

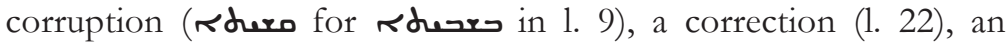
omission of several words (1. 43-44); the colophon and benediction, extant in $\mathrm{MN}$, are absent (1. 50-51), and there are other errors and omissions (1. 23, 44). Florence Jullien distinguishes the West Syriac text of Leg. Silv., identified correctly as a tahwita ("demonstration"),

${ }^{60}$ Jean Baptiste Chabot, "Notice sur les manuscrits syriaques de la Bibliothèque Nationale" ( $J A$ IXe série, 8 [Sept.-Oct. 1896], 256-58); François Nau, "Notice des manuscrits syriacques entrés à la Bibliothèque Nationale de paris depuis l'édition des catalogues (syriacques 289-355)" (ROC 16 [1911], 281). 
from manuscript $\mathrm{O}$ (the only East Syriac witness, besides Budge's edition of the Book of the Bee, in her study), identified as a mimra, "c'est-à-dire d'une homélie versifiée destinée avant tout à édifier," 61 yet there is nothing about the form of the text in $\mathrm{O}$ that is any different from other East and West Syriac manuscripts.

P Solomon of Basra, The Book of the Bee (edition E. A. W. Budge).

Only three Syriac manuscripts of $\mathrm{P}$ have yet been edited, with a fourth in Garšunīi discussed by Budge for comparison. They are represented in the edition below as Pa (London, Royal Asiatic Society, Syr. 1), $\mathrm{Pb}^{\mathrm{b}}$ (London, British Library, Add. 25875), and $\mathrm{Pc}$ (Munich, Bayerische Staatsbibliothek, Cod. Syr. 7). Though all three manuscripts have their own unique readings (note, in this regard, Pa's omission in 1. 24-25 and addition in 1. 14; and $\mathrm{Pb}$ 's addition in 1. 23), most often $\mathrm{Pa}^{a}$ and $\mathrm{Pc}$ agree against $\mathrm{P}^{\mathrm{b}}$. $\mathrm{P}$ is distinguished from the other East Syriac manuscripts by several noteworthy readings: two occasions where P agrees with the West Syriac ("children of Israel," 1. 9; a lengthier reading in v. 6, 1. 19); the omission of the prophecy of Zarathustra (1. 16); and several other significant omissions (1. 10-11, 11-12, 23, and, like $O$, the colophon and benediction in 1. 50-51).

\subsection{The Garšūnī Manuscripts}

The Garšūnī witnesses fall into two major groups: Garšūnī A (GarA) with manuscripts RSTU and Y and Garšūnī B (GarB) consisting solely of $\mathrm{V}$.

R Cambridge, Syriac Add. 2881, 71/4 x 51/4 in, 435 fols., 1484: fol. $136^{\mathrm{v}-139 \mathrm{r} .}{ }^{62}$

The volume is damaged in a number of places with at least one quire missing. It contains a large collection of various texts in Arabic written in Garšūnī (Serto) and Arabic script (Naskhī). Somewhat careless writing and various errors and omissions suggest this is a work of an unskilled copyist working from an

${ }^{61}$ Jullien, "La légende," 210.

${ }^{62}$ Wright, Catalogue of the Syriac Manuscripts in the Library of the University of Cambridge, 713-23. 
imperfect Vorlage. In a number of places, including GarA 1. 5-6 (marked as lacunae in the critical edition), the letters are replaced by numbers, possibly indicating places where the original was illegible. Along with various lives of saints, homilies, theological treatises, and the history of the monks in the desert of Scete, $\mathrm{R}$ contains a number of additional apocryphal works: Acts of Thomas (fol. 53v103v), The Testament of our Lord Jesus Christ to his Disciples on the Mount of Olives (fol. 103 ${ }^{\mathrm{v}}-136^{\mathrm{v}}$ ), the Abgar Correspondence (fol. 158v159v), the Relation of Pontius Pilate regarding the dealings of the Jews with our Lord, written in the year 18 of the reign of the Emperor Tiberius (Anaphora Pilati? fol. 160r-168r), and the History of the Decease of the Virgin Mary (Dorm. Virg.? fol. 223 ${ }^{\mathrm{r}}$ 238 ${ }^{\mathrm{r}}$ ).

S Birmingham, Mingana Syr. 22, 247 x 167 mm., 237 fols., 1527: fol. $134^{\mathrm{v}}-136^{\mathrm{v}} \cdot{ }^{63}$

The manuscript is comprised entirely of Garšunīi texts, one of which is the Life of John the Baptist by Serapion (fol. 29r-48v), found also in Mingana Syr. 369 (Ms E above). The manuscript lacks several pages-between fol. 43-44, 49-50, 50-51, and 71-72-none of which affect Leg. Silv; in addition, the second half of fol. 227 has been cut off (but with no damage to the text), the final text of the manuscript is incomplete at the end, and the final leaf is damaged. The manuscript is dated on fol. $72^{\mathrm{v}}$ by a scribe named Jacob.

T Birmingham, Mingana Syr. 48, 218 x 170 mm., 147 fols., 1906 (but based in part on a manuscript from 1757): fol. 144r-145 ${ }^{\mathrm{r}} \cdot{ }^{64}$

The majority of this manuscript is devoted to texts related to Mary. The first is the West Syriac Life of Mary (fol. 1 ${ }^{\mathrm{r}}$-71v) divided into five books: the Infancy of Mary (fol. $1^{\mathrm{r}}-6^{\mathrm{v}}$ ) and the Birth of Jesus (fol. 6v-10v) drawn from the Protevangelium of James, the Vision of Theophilus (10v-29r), Infancy Gospel of Thomas (29v-32r), and the Dormition of the Virgin $\left(32^{\mathrm{v}-71 v}\right)$. To date, little work has been done on this collection of tales; only the Vision of Theophilus has seen print. ${ }^{65}$ The Life of Mary texts are followed by several memrē

${ }^{63}$ Mingana, Catalogue of the Mingana Collection of Manuscripts, 62-68.

${ }^{64}$ Ibid., 133-37.

65 See Mingana, Woodbrooke Studies, vol. 3, 1-92. Prior to Mingana's edition the work had been made known by way of a summary 
devoted to the Virgin and three letters that came down from heaven (fol. $126^{\mathrm{v}}-134^{\mathrm{v}}$ ). The final three texts of the manuscript are in Garšunni: a miracle of the Virgin attributed to Cyril of Jerusalem (135r-142v), Leg. Silv. (144r-145r), and another miracle "performed by Our Lady Mary the Saint in the days of caliph Ma'mun" (145v150r). Leg. Silv. is preceded by a lengthy colophon $\left(142^{\mathrm{v}}-143^{\mathrm{v}}\right)$ providing the identity of the copyist, and the date and place (Mosul) of production. ${ }^{66}$ The colophon of the manuscript from which this one was copied is reproduced on fol. $143^{\mathrm{v}}$ and reveals that it originated in the village of Baith Khudaidah in 1757. The placement of the Judas text after the colophons suggests it was a late addition to the collection.

U Birmigham, Mingana Syr. 479, 228 x 167 mm, 125 fols., 1819: fol. $123^{\mathrm{v}}-125^{\mathrm{r}} \cdot{ }^{67}$

This manuscript only contains three works: a grammar of Syriac by Timothy Isaac bar Deacon Abd Hayya (also known as Basil Isaac Gobeyr) the Metropolitan of Diyarbakır (1643-1721), a chapter on the Eucharist from the Canons of the Apostles in Garšūnī, and Leg. Silv., likewise in Garšūnī. Written in clear Serto by Abd al-Masih bar Ishaq, a priest.

V Birmigham, Mingana Syr. 514, 161 x 111 mm, 152 fols., 1729 or 1750: $140^{r}-142^{r} .68$

This manuscript contains 19 works from different periods bound together in a single volume. They include three memrē in

presentation in François Nau, "La version syriaque de la vision de Théophile sur le séjour de la Vierge en Egypte," ROC 15 (1910): 125-32. The Vision of Theophilus also exists as an independent text. See CANT 56 and Clavis Patrum Graecorum 2628 for references to various versions. For a precise listing of the available manuscripts see Tony Burke, "The Infancy Gospel of Thomas from an Unpublished Syriac Manuscript. Introduction, Text, Translation, and Notes" (Hugoye 16.2 [2013], 234-36).

${ }^{66}$ The catalog entry report is erroneous in this section. It lists the colophon as fol. 144v-145, Leg. Silv. as fol. 146-147r, and neglects to mention the final text at fol. $145^{\mathrm{v}}-150^{\mathrm{r}}$.

${ }^{67}$ Mingana, Catalogue of the Mingana Collection of Manuscripts, 862-63.

${ }^{68}$ Ibid., 943-48. 
Syriac by Jacob of Serug: a long memrā on the destruction of Jerusalem (1-25v), a shorter unfinished one on the Virgin looking at the crucified Christ (26r-29r), and one on strangers who die in a foreign land $(79 \mathrm{v}-83 \mathrm{v})$. The first two of these are written by the same hand. Only one additional work is in Syriac: a brief history of Nestorius before a council of bishops (144v-149r). The rest of the volume is taken up by works in Garšūni and contains historical and theological treatises, commentaries, prayers, and various apocryphal material. Along with Leg. Silv., these works include two works on miracles of the Virgin, one describing a miracle perfomed during

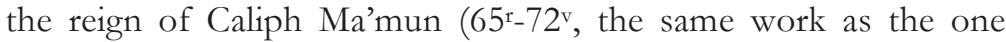
found in Ms N), the other a miracle in a convent in Damascus $\left(73^{r_{-}}\right.$ 79v). All the works in Garšunī and the Nestorius treatise are written by chorbishop Abdallah in clear but inelegant Serto. The dates are given in two colophons on fol. $128^{\mathrm{r}}$ and $143^{\mathrm{v}}$.

Y Mardin, Dayr Al-Zafaran 240, size not specified, 117 fols., 19th $/ 20^{\text {th }}$ cent.: fol. $95^{\mathrm{r}-97 \mathrm{v} .69}$

Along with Leg. Silv., this manuscript contains five stories and two treatises, all in Garšunin, including one by Jacob of Serug titled "On the Holy Mysteries, Confession, and Repentance" (32v-39r). It is written in elegant Serto with colored titles and diacritics. The scribe is identified on fol. 3-4 as Iliyas Adam.

The Garšūnī manuscripts are so divergent in their wording that it is impossible to speak of a single Garšūnī recension of Leg. Silv., nor can any of them be traced directly to one of the Syriac recensions. Of the two groups of witnesses, GarB is the closest to the two Syriac recensions, especially ESyr, with which it shares a number of features, such as the reference to the merchants falling asleep at the side of the road (1.18-19) and the shorter version of the exchange between Abgar and the merchants (1. 34-38). GarA manuscripts, on the other hand, show a number of similarities to WSyr, such as the details of the transaction between the shepherds and the merchants (1. 28-34), the mention of an inn (1. 36), and a reference to Jesus' knowledge of secrets (1. 53). Additionally, GarA

${ }^{69}$ Cataloged on the Hill Museum and Manuscript Library web site: http://www.vhmml.us/research2014/catalog/detail.asp?MSID=122639. Cited 1 July 2014. 
contains a number of independent innovations when compared to the Syriac versions and GarB. These include the mention of the shepherds giving water to their sheep (1.28) and the reference to the priests showing Judas the pieces and using them to tempt him (1. 57).

The manuscripts within the GarA group fall into two subgroups. The first one comprises manuscripts $\mathrm{T}$ and $\mathrm{U}$, which show by far the largest degree of agreement to the point of being nearly identical. However, they also display a number of small, but consistent differences (such as the spelling of Isaac's name or the plural of "shepherd") which make it clear that one is not a copy of the other, but that they both are close branches of a single tradition. In terms of content, $\mathrm{T}$ and $\mathrm{U}$ are the only Garšun $\overline{1}$ manuscripts which, like ESyr, make a reference to the prophecy of Zarathustra, albeit in the guise of Bal'am, whom the Arabic tradition identifies with Zarathustra. On the other hand, T and U stand unique in a number of aspects-for example, they both describe the placement of the coins on Solomon's temple in greater detail than all the other manuscripts in both languages (1. 6-8), and they both lack a reference to Abgar's observation on the uniqueness of the Seamless Robe (1. 40).

Manuscripts R, S, and $\mathrm{Y}$, which together make up the second subgroup of GarA, are far more divergent, both in appearance and content, with R clearly standing against S and Y. Only S and Y can be considered complete while $\mathrm{R}$ shows a number of lacunae (such as 1. 4-6) and while all three manuscripts contain an elaborate introduction, only $\mathrm{R}$ concludes the narrative in an equally elaborate fashion. The same relationship between the three manuscripts is also reflected in the content, with $\mathrm{S}$ and $\mathrm{Y}$ agreeing with each other in a number of places against $\mathrm{R}$. The most notable examples are the lack of mention in $\mathrm{R}$ of how the priests showed the pieces to Judas (1. 57) ( $\mathrm{R}$ is the only Garšunī manuscript which omits this) and the reference to the cemetary for strangers (1.60)— $\mathrm{R}$ directly mentions a "potter's field" as an afterthought while S and Y speak of a "potter's land" when mentioning the purchase. In other places, however, agreement is fluid and in a number of instances $\mathrm{Y}$ stands alone, such as in its shorter version of the description of the transaction over the Robe and the pieces (1. 35-38) and the description of the origin of the Robe (1. 43). 
Finally, when comparing the Syriac and Garšunnī versions of Leg. Silv., one cannot help but notice the distinct nature of the preserved witnesses: both branches of the Syriac tradition show relative uniformity and little substantial disagreement, whereas the Garšūni versions are not only different from either of the Syriac recensions, but they also differ wildly from each other. This applies to content (especially when introducing elements not found in Syriac) as well as language-whether orthography, morphology (such as the four different plurals for the word "shepherd"), or choice of words (the inversion of the words for "inn" between U and $\mathrm{Y}$ on the one hand and $\mathrm{S}$ and $\mathrm{T}$ on the other). The variation in the Garšun $\overline{1}$ tradition is thus reminiscent of the variation in other types of popular literature, such as fairy tales, which are primarily transmitted orally. This not only illustrates the popularity of Leg. Silv., but it suggests also that while the Syriac recensions followed the usual patterns of written transmission, the Garšunin version was told, retold, and then written down over and over again. As such, the history of Leg. Silv. is also a witness to the language shift from Syriac to Arabic in the Christian communities of the Middle East.

\section{ARMENIAN VERSION}

The Armenian version is found in two manuscripts discussed in an essay on the Abgar Legend by Bernard Outtier. ${ }^{70}$ The manuscripts are: Erevan, Matenadaran no. 3854 (1471), fol. 80v-88v and Erevan, Matenadaran no. 7993 (1692), fol. 152v-153v. ${ }^{71}$ The story weaves in and out of the Abgar Legend. In Edessa, Abgar instructs Addai to find a garment fitting as a gift for Jesus. As they are speaking, some merchants appear with the Seamless Robe and present it to Adaai. Recalling Leg. Silv. v. 10-11, the merchants tell the king how they obtained the Robe, and Addai takes the Robe from the merchants and the pieces from the shepherds and has Addai bring them to Jesus along with the letter requesting healing from his disease. After Addai returns to Edessa with Jesus' response to Abgar, Jesus

${ }^{70}$ Bernard Outtier, "Une forme enrichie de la Légende d'Abgar en arménien," in V. Calzolari Bouvier, J.-D. Kaestli, and B. Outtier, eds., Apocryphes arménians: transmission- traduction-creation-iconographie; Acts du colloque international sur la literature apocryphe en langue arménienne (Genève, 18-20 septembre 1997) (Lausanne: Éditions du Zébre, 1999), 129-145.

${ }^{71}$ See H. S. Anasian, Bibliologie arménienne, vol. 1 (Erévan: Académie des Sciences, 1959), 5-6. 
tells the disciples where the money from Abgar came from, relating an abbreviated version of the remaining portions of the story from Leg. Silv.

Many elements of the Armenian version of the tale have parallels in the Latin sources: Abraham uses the money to buy a cave from the "son of Amor," from whom it comes into the hands of the Edessenians, who use it to buy Joseph from his brothers; the brothers then bring the money to Pharaoh; later, the priests use the pieces returned to them by Judas to pay the guards at the tomb, but the guards refuse it, saying, "This money should not be kept, because it is the price of blood." So the priests buy the potter's field. These parallels with the Latin witnesses lead Florence Jullien to conclude that there may be some truth to Godfrey of Viterbo's claim to have found Leg Silv. in a sermon by the apostle Bartholomew to the Armenians. ${ }^{72}$ Indeed, the Armenian text does contain elements common to both Eastern and Western traditions.

\section{Additional Stories of THE ORIGIN OF THE THIRTY PIECES OF SILVER}

Another story (Leg. Silv. Rings) of the origin of the thirty pieces of silver has been published in Latin, ${ }^{73}$ Greek, ${ }^{74}$ Arabic ${ }^{75}$ and Amharic, ${ }^{76}$

72 Jullien, “La légende," 217-18, 220.

73 See Hill, "Thirty Pieces," 102-3 for a summary of the Latin text reproduced in Arthur S. Napier, History of the Holy Rood-tree (EETS, Old Series 103; London: Oxford University Press, 1894), 69.

74 Jakob Gretser (Hortus Sanctae Crucis [Ingolstadt, 1610], 233) mentions the story from a cross legend found in two manuscripts of a twelfth-century Greek synaxarion. See the discussion in Wilhelm Meyer, "Die Geschichte des Kreuzholzes vor Christus," Abhandlungen der philosophisch-philologischen Classe der Königlich Bayerischen Akademie der Wissenschaften 16 (1882): 156.

${ }^{75}$ Carl Bezold, Kebra Nagast, die Herrlichkeit der Könige (Munich: Verlag der Könglichen Bayerischen Akademie der Wissenschaften, 1905), xliv ff. For the English translation, see Ernest A. W. Budge, The Queen of Sheba and Her Only Son Menyelek (London: Martin Hopkinson \& Co., 1922), xxxix-xlv. Georg Graf (Geschichte der christlichen arabischen Literatur, vol. 1 [Vatican City: Biblioteca Apostolica Vaticana, 1944], 210) includes this story in the circle of legends surrounding the building of Solomon's temple and cites two Arabic manuscript sources: Strasbourg, Bibliothèque nationale et universitaire, or. 4180 (ar. 33), fol. 189r $-192^{\mathrm{r}}$ (16th cent.; described by Graf as being a part of "einer seltsamen Miszellaneen- 
with the latter possibly being a translation of the former. This particular version differs considerably from Leg. Silv. and it ties the story of the silver pieces to the origin of the wood from which the True Cross was made. According to the Arabic version of the story, Solomon commanded his hunters to capture a young Rukh bird and hold it in a brass pot. Its mother saw this, flew up to Paradise, picked up a piece of wood which was lying there, brought it back to Jerusalem and dropped it onto the brass pot which broke and released the young bird. Solomon knew this was no ordinary piece of wood and he ordered his masons to use it in the construction of the Temple. Once the Temple was finished, Solomon placed the piece of wood in the entrance to the Temple. When the Queen of Sheba visited Solomon and learned of the story of the piece of wood, she adorned it with a silver ring and so did Solomon and all who reigned in Israel after him, until there were thirty pieces of silver attached to it. When Judas came to the priests to betray Christ, they stripped the silver from the wood and gave it to Judas, and the wood was made into the cross on which Christ was crucified. The Latin version begins differently, with Moses encountering three rods of cypress, cedar, and pine. These rods are passed down to David and he plants them in Jerusalem, where they grow together into one tree. Every year, for thirty years, David adds a silver ring to the tree; the rings expand as the tree grows. When Solomon builds the temple, a beam is needed, so the tree is cut down and the thirty silver rings are hung in the temple.

Sammlung"); and Cairo, Patriarchal Library (the Coptic Catholic Patriarchate), 645, fol. 166 ${ }^{\mathrm{v}}$ (1719). Another source for this text is a manuscript from St. Mark's Cathedral (the Coptic Orthodox Patriarchate) microfilmed by Brigham Young University under the designation COP 66 (http://cpart.mi.byu.edu/home/manuscripts/cop/, the manuscript images are available at https://archive.org/details/COP6-6, both cited 18 January 2016.) Leg. Silv. Rings can be found on $172^{\mathrm{r}}-173^{\mathrm{v}}$ (according to Arabic foliation; fol. 183-184 according to the foliation in Coptic numerals) under the title "The story of the thirty silver rings" as a part of a collection of shorter texts. This is the same collection of miscellanea as the one in BNU Strassburg or. 4180 which includes, among others, a copy of the Arabic recension of Testament of Adam.

76 Thomas L. Kane, "An Amharic Version of the Origin of the Cross," BSAOS 44. 2 (1981): 273-89. 
Another Cairo manuscript, CMB 12-6 in the Macomber index, is mentioned by Jullien. ${ }^{77}$ The relevant entry in the catalog of the Coptic Museum manuscripts by Simaika and Abd al-Masih ${ }^{78}$ gives the title of the work as "Mìmar on the 30 pieces of silver for which Judas betrayed the Savior" and describes it as spanning 33 folios with 15 lines per page. This manuscript, written in the Arabic language in Arabic script and foliated in Coptic numerals, does indeed contain another Arabic recension of Leg. Silv, albeit an incomplete one. The text of Leg. Silv. begins on fol. $1^{\mathrm{r}}$ at the end of Leg. Silv. 6 and shows most similarity to the GarA recension, agreeing at times with the RSY group of manuscripts, then at others with the TU group. The story of the 30 silver pieces concludes on fol. $3^{\mathrm{r}}$ with Judas accepting them for his betrayal of Christ. The text then turns into a memra on Judas himself. A separate edition of the recension of Leg. Silv. in CMB 12-6 will be published by the present authors at a later point.

\section{Motif TABLE}

77 Jullien, "La légende," 213 n. 19. See William F. Macomber, Final Inventory of the Microfilmed Manuscripts of the Coptic Museum Old Cairo, Egypt (Provo, Utah: Brigham Young University, 1995), 73, 86.

${ }^{78}$ Serial No. 116, Call No. Hist. 276 in Marcus Simaika Pasha and Yassa Abd al-Masih Effendi, Catalogue of the Coptic and Arabic Manuscripts in the Coptic Museum, the Patriarchate, the Principal Churches of Cairo and Alexandria and the Monasteries of Egypt in 3 Volumes, vol. 1 (Cairo: Government Press, 1939), 61. 


\begin{tabular}{|c|c|c|c|c|c|}
\hline $\begin{array}{l}\text { Terah created the coins; he } \\
\text { gave them to Abraham }\end{array}$ & $\mathrm{X}$ & $\mathrm{X}$ & $\mathrm{X}$ & $\mathrm{X}$ & $\mathrm{X}$ \\
\hline $\begin{array}{l}\text { Abraham gave them to Isaac; } \\
\text { Isaac bought a village }\end{array}$ & $\mathrm{X}$ & $\mathrm{X}$ & $\mathrm{X}$ & $\mathrm{X}$ & $\mathrm{X}$ \\
\hline $\begin{array}{l}\text { Master of the village gave } \\
\text { them to the Pharaoh }\end{array}$ & $\mathrm{X}$ & $\mathrm{X}$ & $\mathrm{X}$ & $\mathrm{X}$ & $\mathrm{X}$ \\
\hline ... to honor him & & & $\mathrm{X}$ & $\mathrm{X}$ & \\
\hline $\begin{array}{l}\text { Pharaoh gave them to } \\
\text { Solomon for the Temple }\end{array}$ & $\mathrm{X}$ & $\mathrm{X}$ & $\mathrm{X}$ & $\mathrm{X}$ & $\mathrm{X}$ \\
\hline $\begin{array}{l}\text { Solomon put them around the } \\
\text { door to the sanctuary }\end{array}$ & $\mathrm{X}$ & $\mathrm{X}$ & $\mathrm{X}$ & $\mathrm{X}$ & $\mathrm{X}$ \\
\hline$\ldots$ ten here, ten there & & & & $\mathrm{X}$ & $\mathrm{X}$ \\
\hline $\begin{array}{l}\text {..ten on the left, ten on the } \\
\text { right }\end{array}$ & & & $\mathrm{X}$ & & \\
\hline $\begin{array}{l}\text { Nebuchadnezzar finds them in } \\
\text { the Temple }\end{array}$ & $\mathrm{X}$ & $\mathrm{X}$ & $\mathrm{X}$ & $\mathrm{X}$ & $\mathrm{X}$ \\
\hline $\begin{array}{l}\text { Nebuchadnezzar brings them } \\
\text { to Babel with captives }\end{array}$ & $\mathrm{X}$ & $\mathrm{X}$ & $\mathrm{X}$ & $\mathrm{X}$ & $\mathrm{X}$ \\
\hline $\begin{array}{l}\text { Nebuchadnezzar has Persian } \\
\text { hostages }\end{array}$ & $\mathrm{X}$ & $\mathrm{X}$ & & $\mathrm{X}$ & $\mathrm{X}$ \\
\hline ...or servants & & & $\mathrm{X}$ & & \\
\hline $\begin{array}{l}\text { Persian kings send } \\
\text { Nebuchadnezzar gifts worthy } \\
\text { of kings }\end{array}$ & $\mathrm{X}$ & $\mathrm{X}$ & $\mathrm{X}$ & $\mathrm{X}$ & $\mathrm{X}$ \\
\hline ... and beautiful & $\mathrm{X}$ & & $\mathrm{X}$ & $\mathrm{X}$ & $\mathrm{X}$ \\
\hline
\end{tabular}




\begin{tabular}{|c|c|c|c|c|c|}
\hline $\begin{array}{l}\text { Nebuchadnezzar sends Persian } \\
\text { children home with coins }\end{array}$ & $\mathrm{X}$ & $\mathrm{X}$ & $\mathrm{X}$ & $\mathrm{X}$ & $\mathrm{X}$ \\
\hline $\begin{array}{l}\text { When Christ was born and } \\
\text { they saw the star }\end{array}$ & $\mathrm{X}$ & $X$ & $X$ & $\mathrm{X}$ & $\mathrm{X}$ \\
\hline$\ldots$ as foretold by Zarathustra & & $\mathrm{X}$ & $\mathrm{X}$ & & \\
\hline $\begin{array}{l}\ldots \text { they took the coins and } \\
\text { gold, myrrh and frankincense }\end{array}$ & $X$ & $\mathrm{X}$ & $X$ & $\mathrm{X}$ & $\mathrm{X}$ \\
\hline $\begin{array}{l}\text { The kings stopped in/near } \\
\text { Edessa }\end{array}$ & $\mathrm{X}$ & X & X & $\mathrm{X}$ & $\mathrm{X}$ \\
\hline ....at a well & & & $\mathrm{X}$ & $\mathrm{X}$ & \\
\hline ...or at the side of the road & $\mathrm{X}$ & $\mathrm{X}$ & & & $\mathrm{X}$ \\
\hline ...they fell asleep & $\mathrm{X}$ & $\mathrm{X}$ & $\mathrm{X}$ & $\mathrm{X}$ & \\
\hline ...leaving the coins behind & $\mathrm{X}$ & $\mathrm{X}$ & $\mathrm{X}$ & $\mathrm{X}$ & $\mathrm{X}$ \\
\hline $\begin{array}{l}\text { Some merchants found the } \\
\text { coins }\end{array}$ & $\mathrm{X}$ & $\mathrm{X}$ & $\mathrm{X}$ & $\mathrm{X}$ & $\mathrm{X}$ \\
\hline $\begin{array}{l}\text { The merchants stopped at a } \\
\text { well near Edessa }\end{array}$ & $\mathrm{X}$ & $\mathrm{X}$ & $\mathrm{X}$ & $\mathrm{X}$ & $\mathrm{X}$ \\
\hline $\begin{array}{l}\text { An angel came to shepherds, } \\
\text { gave them Seamless Robe }\end{array}$ & $\mathrm{X}$ & $\mathrm{X}$ & $\mathrm{X}$ & $\mathrm{X}$ & $\mathrm{X}$ \\
\hline Shepherds came to the well & $\mathrm{X}$ & $\mathrm{X}$ & $\mathrm{X}$ & $\mathrm{X}$ & $\mathrm{X}$ \\
\hline ...for water for their sheep & & & $\mathrm{X}$ & $\mathrm{X}$ & \\
\hline $\begin{array}{l}\text { They asked the merchants to } \\
\text { buy the Robe }\end{array}$ & $\mathrm{X}$ & $X$ & $X$ & $\mathrm{X}$ & $\mathrm{X}$ \\
\hline
\end{tabular}




\begin{tabular}{|c|c|c|c|c|c|}
\hline $\begin{array}{l}\text { Merchants marveled at it and } \\
\text { gave coins in exchange }\end{array}$ & $\mathrm{X}$ & $\mathrm{X}$ & $\mathrm{X}$ & $\mathrm{X}$ & $\mathrm{X}$ \\
\hline Merchants came to Edessa & & $\mathrm{X}$ & $\mathrm{X}$ & $\mathrm{X}$ & $\mathrm{X}$ \\
\hline ...or an unnamed city & $\mathrm{X}$ & & & & \\
\hline ....and stopped at an inn & $\mathrm{X}$ & & $\mathrm{X}$ & $\mathrm{X}$ & \\
\hline $\begin{array}{l}\text { Abgar the king of Edessa sent } \\
\text { for the merchants }\end{array}$ & $\mathrm{X}$ & $\mathrm{X}$ & $\mathrm{X}$ & $\mathrm{X}$ & $\mathrm{X}$ \\
\hline $\begin{array}{l}\text { He asked merchants if they } \\
\text { had something worthy of kings }\end{array}$ & $\mathrm{X}$ & $\mathrm{X}$ & $\mathrm{X}$ & $\mathrm{X}$ & $\mathrm{X}$ \\
\hline $\begin{array}{l}\text { Merchants said they had the } \\
\text { Seamless Robe }\end{array}$ & $\mathrm{X}$ & $\mathrm{X}$ & & & $\mathrm{X}$ \\
\hline $\begin{array}{l}\text { Merchants brought in the } \\
\text { Robe along with other } \\
\text { clothing }\end{array}$ & & & $\mathrm{X}$ & $\mathrm{X}$ & \\
\hline $\begin{array}{l}\text { King saw the Robe and that it } \\
\text { was unique }\end{array}$ & $\mathrm{X}$ & $\mathrm{X}$ & & $\mathrm{X}$ & $\mathrm{X}$ \\
\hline $\begin{array}{l}\text { King asked where they got it } \\
\text { from }\end{array}$ & $\mathrm{X}$ & $\mathrm{X}$ & $\mathrm{X}$ & $\mathrm{X}$ & $\mathrm{X}$ \\
\hline $\begin{array}{l}\text { Merchants said they came to a } \\
\text { well and met the shepherds }\end{array}$ & $\mathrm{X}$ & $\mathrm{X}$ & $\mathrm{X}$ & $\mathrm{X}$ & $\mathrm{X}$ \\
\hline $\begin{array}{l}\text { Shepherds asked the } \\
\text { merchants to buy the Robe }\end{array}$ & $\mathrm{X}$ & & $\mathrm{X}$ & $\mathrm{X}$ & \\
\hline $\begin{array}{l}\text { Merchants looked at it and saw } \\
\text { that it was unique }\end{array}$ & $\mathrm{X}$ & & $\mathrm{X}$ & $\mathrm{X}$ & \\
\hline Merchants said they had coins & $\mathrm{X}$ & & $\mathrm{X}$ & $\mathrm{X}$ & \\
\hline $\begin{array}{l}\text {...with images of kings on } \\
\text { them }\end{array}$ & $\mathrm{X}$ & & $\mathrm{X}$ & $\mathrm{X}$ & \\
\hline
\end{tabular}


Motif

WSyr ESyr GarA GarA GarB

(TU) (RSY)

\begin{tabular}{|c|c|c|c|c|c|}
\hline $\begin{array}{l}\text { Merchants buy the Robe; coins } \\
\text { are worthy of a king }\end{array}$ & $\mathrm{X}$ & $\mathrm{X}$ & $\mathrm{X}$ & $\mathrm{X}$ & $\mathrm{X}$ \\
\hline $\begin{array}{l}\text { King sent for shepherds and } \\
\text { took the coins }\end{array}$ & $\mathrm{X}$ & $\mathrm{X}$ & $\mathrm{X}$ & $\mathrm{X}$ & $\mathrm{X}$ \\
\hline $\begin{array}{l}\text {... and gave the merchants } \\
\text { their equivalent in weight }\end{array}$ & & & $\mathrm{X}$ & $\mathrm{X}$ & \\
\hline $\begin{array}{l}\text { King sent coins and Seamless } \\
\text { Robe to Jesus for curing him }\end{array}$ & $\mathrm{X}$ & $\mathrm{X}$ & $\mathrm{X}$ & $\mathrm{X}$ & $\mathrm{X}$ \\
\hline $\begin{array}{l}\text { Jesus kept the Robe and sent } \\
\text { coins to the treasury }\end{array}$ & $\mathrm{X}$ & $\mathrm{X}$ & $\mathrm{X}$ & $\mathrm{X}$ & $\mathrm{X}$ \\
\hline $\begin{array}{l}\text {...he was happy to have the } \\
\text { Robe and put it on }\end{array}$ & & & & & $\mathrm{X}$ \\
\hline ...in the Temple & & & $\mathrm{X}$ & $\mathrm{X}$ & $\mathrm{X}$ \\
\hline $\begin{array}{l}\text { He knew their secrets and that } \\
\text { he would be bought with them }\end{array}$ & $\mathrm{X}$ & & $\mathrm{X}$ & $\mathrm{X}$ & $\mathrm{X}$ \\
\hline $\begin{array}{l}\text { The Jews came to Judas and } \\
\text { said to him "Deliver Jesus to } \\
\text { us" }\end{array}$ & $\mathrm{X}$ & & $\mathrm{X}$ & $\mathrm{X}$ & \\
\hline Judas approached the Jews & & $\mathrm{X}$ & & & $\mathrm{X}$ \\
\hline $\begin{array}{l}\text { Judas asked for the price of } \\
\text { betraying Jesus }\end{array}$ & $\mathrm{X}$ & $\mathrm{X}$ & $\mathrm{X}$ & $\mathrm{X}$ & $\mathrm{X}$ \\
\hline The Jews brought the coins & $\mathrm{X}$ & $\mathrm{X}$ & $\mathrm{X}$ & $\mathrm{X}$ & $\mathrm{X}$ \\
\hline $\begin{array}{l}\text {...and showed them to Judas to } \\
\text { tempt him }\end{array}$ & & & $\mathrm{X}$ & $\mathrm{X}$ & \\
\hline ...then gave them to Judas & $\mathrm{X}$ & $\mathrm{X}$ & $\mathrm{X}$ & $\mathrm{X}$ & $\mathrm{X}$ \\
\hline When Judas repented & & $\mathrm{X}$ & $\mathrm{X}$ & $\mathrm{X}$ & $\mathrm{X}$ \\
\hline
\end{tabular}




\begin{tabular}{llllll}
\hline ...he returned them to the Jews & $\mathrm{X}$ & $\mathrm{X}$ & $\mathrm{X}$ & $\mathrm{X}$ & $\mathrm{X}$ \\
...and hanged himself & & $\mathrm{X}$ & & & \\
The Jews used the coins to & $\mathrm{X}$ & $\mathrm{X}$ & $\mathrm{X}$ & $\mathrm{X}$ & $\mathrm{X}$ \\
buy the potter's field \\
$\begin{array}{l}\text { They threw the remaining } \\
\text { coins into a well in the Temple }\end{array}$ \\
$\begin{array}{l}\text {...ang with the Staff of } \\
\text { Moses }\end{array}$ \\
$\begin{array}{l}\text {...and so hid them } \\
\text { X }\end{array}$
\end{tabular}

\section{ORIGINS AND TRANSMISSION}

Leg. Silv. has a rich manuscript tradition in Syriac and Garšūnī alone; add to these the sources in Armenian, Latin, and the European vernaculars and it becomes very complicated to determine the paths of the text's transmission. At least for the Garšunin tradition, the transmission of Leg. Silv. worked somewhat like that of a fairy tale, with various alterations taking place through oral performance and subsequent return to written form. Some changes in the versions came through translation from one language to another, and still others from the writers' desire to elaborate and enhance the tale with additional biblical traditions, local legends, and histories of other relics of the Passion. All of these changes make establishing a single authoritative text a difficult, if not impossible, task.

The two Syriac recensions are so structurally and syntactically alike that it is evident they are variations on a common text. Nevertheless, there are several noteworthy differences: the mention of the prophecy of Zarathustra (ESyr; Bal'am in GarA manuscripts TU), the lengthier retelling of the merchants' acquisition of the Seamless Robe (WSyr), the statement that Jesus knew the secrets of the priests (WSyr and GarAB), the role of Judas (ESyr GarB) rather than the priests (WSyr and GarA) as instigator of the plot against Jesus, and the deposition of the coins in the temple fountain (WSyr and GarAB) along with the Staff of Moses (WSyr only). Unfortunately, it is not possible to determine which reading in each 
of these cases is the original. There is agreement throughout the tradition, however, on several unusual features: the events jump several centuries from Isaac's purchase of the village (ca. 18th cent. $\mathrm{BCE}$ ) to the village master's transfer of the coins to the Pharaoh of Exodus (ca. 13th century); then a Pharaoh (presumably the same one, despite the historical difficulties) gives the coins to Solomon three centuries later; time is shortened again in the Edessa section from when the Magi lose the coins during Jesus' infancy to when they are found by the merchants in Jesus' adulthood. Also problematic is the Syriac tradition's occasional naming of Nebuchadnezzar as the king of Persia (see v. 4), rather than Babylon, and King Abgar is healed before Jesus' death (v. 11), rather than after, as in the Abgar Legend (Eusebius, Hist. eccl. 1.13.5; Doctr. Addai 10).

When the author/redactor created the Syriac text is unknown. Solomon of Basra incorporated it into his Book of the Bee in the thirteenth century, but the authors of the earlier Chronicle of Zuqnin (8th cent.) and the Cave of Treasures (ca. 6th cent.), were either unaware of or uninterested in the text. ${ }^{79}$ Florence Jullien believes Leg. Silv. is a Syriac composition. ${ }^{80}$ As evidence, she cites the interest in garment imagery in the East and what she sees as a meaningful structure evident only in the Syriac/Garšūnī tradition. Jullien argues that the Syriac author draws upon the concept of the seven-year Jubilee to arrange the story into two seven-stage periods: one representing Old Testament history (from Terah to Nebuchadnezzar), and the other New Testament history (from the Magi to Judas). ${ }^{81}$ Jullien then postulates that the text was translated from Syriac into Armenian, and it is this Armenian version that was available to Godfrey, ${ }^{82}$ who claims to have found his text in a Hebrew sermon of the apostle Bartholomew to the Armenians; further support may be found in Godfrey's inclusion of an Armenian astrologer. But there are problems with Jullien's theory.

${ }^{79}$ Hill, "Thirty Pieces," 94 makes more of this than is warranted. He says that both of these earlier writers report that the gifts to Jesus from the Magi came from the cave of Adam, a legend that Solomon is challenging in his incorporation of Leg. Silv.; however, unlike the Western writers, Solomon makes no association between the coins and the gifts.

80 Jullien, "La légende," 215-18.

81 Ibid., 214-15.

${ }^{82}$ Ibid., 220. 
First, garment imagery is certainly important in Syriac thought, but the Seamless Robe does not play the same role in Leg. Silv. as garments do in other Syriac literature. Second, the double sevenstage transmission simply does not work: Nebuchadnezzar gives the coins to the Persian kings, the eighth Old Testament-era bearers of the silver pieces, unless one considers the Persian kings and the Magi a single stage, but this disrupts the Old Testament/New Testament dichotomy. Third, it is unwise to put much stock in the Western writers' elaborate claims of Eastern origins for the legend; and Godfrey's is the most doubtful of them all-indeed, not only does he not say his version of the legend derives from an Armenian text but translation from Armenian to Latin is an extremely unlikely pathway of transmission.

What, then, can be said about the existence of Leg. Silv. prior to Solomon of Basra? If the Western tradition does not derive directly from the Eastern (whether via Syriac or Armenian), then agreements between the two traditions should be meaningful for establishing an early form of the text. The Latin and Syriac/Garšun in stories begin the same: Terah mints the coins and passes them on to his son Abraham. After Abraham the coins eventually come to Egypt - whether via a master of a village, who receives them from Isaac and then brings them to Pharaoh (Syriac/Garšūnī), or via several additional stages in the Latin sources (from Abraham, to the Ishmaelites, to Joseph's brothers, then to the treasurer of Joseph). The traditions then agree that the pieces are given to Solomon for the building of the temple, either via the Pharaoh (Syriac/Garšunni) or the Queen of Sheba (Latin). Nebuchadnezzar takes the pieces when he plunders the Temple, and he gives them to kings of the East, with whom they remain until the birth of Jesus. The Magi bring the coins on their journey along with their traditional gifts, but in the Syriac/Garšunī version, the Magi lose the coins, and they end up in the hands of King Abgar, who also acquires the Seamless Robe. In the Latin witnesses, the Magi give the coins to Mary, but she loses them during the flight to Egypt. Though the two traditions diverge considerably here, it is noteworthy that they both include the element of the loss of the coins. The pieces return to Jesus via Abgar (Syriac/Garšūnī) or, in the Western sources, via either a shepherd (John and Ludolphe) or an Armenian astrologer who 
recovers them from shepherds (Godfrey). ${ }^{83}$ In all sources, Jesus directly or indirectly places the coins in the treasury, from where the high priests take them and give them to Judas to betray Jesus. Then Judas returns the coins and the high priests use them to buy the potter's field (in the Latin sources, 15 coins are paid for the field and 15 are given to the guards at Jesus' tomb). The texts conclude with a variety of accounts of the fate of the coins. In sum, the common sequence in the transmission is: Terah, Abraham, Pharaoh/Joseph, Solomon, Nebuchadnezzar, Magi, loss and return, Jesus, High Priests, Judas, potter's field.

Of all the Latin sources, Godfrey of Viterbo's Pantheon contains the most correspondences with the Syriac/Garšunin tradition. He alone mentions the Seamless Robe, ${ }^{84}$ saying that the Robe was sent from heaven after the Magi returned home and that its magical qualities included the ability to grow longer as Jesus grew in stature (st. 9-10). He returns to this point later when Jesus is given the Robe as an adult and it stretches to fit him (st. 15). He also mentions the death of Judas (st. 17), whereas the other Latin authors only state that Judas returned the coins. These commonalities are enough for Hook and Hill to think Godfrey and Solomon drew on a common, earlier tradition. ${ }^{85} \mathrm{~A}$ common tradition is certain, but it is not clear where that originated nor in what form. The Seamless Robe is an integral part of the Eastern tradition but its presence in Godfrey may result from the phenomenon of attraction of relics legends-observable also in the addition of the Staff of Moses in WSyr, and the purple cloak (in the hands of the merchants along with the Seamless Robe) in Arm. The inclusion of Judas' death also lacks significance, as Godfrey's account, pieced together from Matt 27:5 and Acts 1:18, could be his own effort to embroider and harmonize the text with biblical traditions.

${ }^{83}$ Note that, in some of the Latin manuscripts, the coins are not lost and Mary gives them to the shepherds at Jesus' birth (from Luke 2:8-20; Paris, BnF NAL 543 and London, BL 22553) or directly to the temple for the child's redemption (from Luke 2:22-40; London, BL Add. 34139).

${ }^{84} \mathrm{John}$ of Hildesheim also mentions the Robe, but not in the course of the story. The Robe is named along with the coins as relics that were passed along after the death of Jesus via hereditary succession.

${ }^{85}$ Hook, "Legend," 206-7; Hill, “Thirty Pieces," 95. 
When the Armenian version is added to the discussion, more agreements between the Eastern and Western traditions come into view. Arm includes mention of the burial cave (purchased from "the Son of Amor" in Arm; John of Hildesheim says Abraham bought it for his wife and sons in Hebron [cf. Gen 23]), the sale of Joseph (to the "Edessenians" in Arm) and subsequent donation of the coins to Joseph, and the coins as payment to the guards at the tomb. Though none of these elements are present in the Syriac/Garšun ī witnesses, it is tempting to include them as components of the original text, either in a Syriac exemplar less developed than that used by ESyr, WSyr, GarA, and GarB or in another language. Perhaps all versions derive from a lost Greek original, translated into Syriac and Armenian (either directly or via a Syriac intermediary) on the one hand and Latin on the other. Likely the Abgar material was added in a Syrian milieu, though given the variety of ways the coins were lost and found again in the Latin versions, it is possible that something, either the Abgar story or another version of this stage of the legend, has dropped out of the Western text at some early stage of its transmission.

The ultimate origin of Leg. Silv. lies somewhere between the second century, when the authority of the Gospels has become established, and the fifth or sixth century, when we see a surge of interest in relics of the crucifixion. The earliest form of the Legend of the True Cross (in Gelasius of Caesarea's Historia Ecclesiastica) dates to ca. 390 C.E., though the cross was being venerated already in Jerusalem as early as the 320s. ${ }^{86}$ Along with the True Cross, Helena, the mother of Constantine, is said to have found the nails of the crucifixion, the Holy Lance (John 19:34), the Seamless Robe, and the titulus that was nailed above the cross (Mark 15:26 par.; John 19:19-22). The discovery of the Crown of Thorns, the Holy Sponge, and other relics followed in due course. ${ }^{87}$

86 See further Jan Willem Drijvers, Helena Augusta: The Mother of Constantine the Great and the Legend of Her Finding of the True Cross (Leiden/New York: Brill, 1992).

${ }^{87}$ For a brief overview of the transmission of the Seamless Robe relic see Bernhard Schneider, "Holy Coat," in Religion Past and Present (12 vols.; ed. Hans Dieter Betz, Don S. Browning, Bernd Janowski, and Eberhard Jüngel; Leiden: Brill, 2006-2013), 6:218-219. Three cities today claim to possess the relic: Trier, Argenteuil, and Mtskheta (Georgia). The Trier 
Over time, legends relating to the cross were expanded with extensive pre-histories similar to the origins of the coins in Leg. Silv. Some variations of the True Cross legend trace the origin of the cross to the Tree of Life. ${ }^{88}$ From the tree was crafted the Staff of Moses, which was used in building the temple, and then the staff was re-used for a bridge over the pool Bethzatha (John 5:2), and finally it became the cross of Jesus. ${ }^{89}$ Another account, from the fourteenth-century Sarajevo Haggadah, again states that the staff, also referred to as the Rod of Aaron, originated in pre-historic times: it was created by God on the sixth day of Creation. It was delivered to Adam, and then passed down until it was stolen from Joseph and given to Jethro. Like the story of Excalibur, no-one could remove the staff from the ground until Moses appeared, withdrew the staff and thus won the hand of Zipporah. The Staff of Moses is featured also in the ninth-century Midrash Yelamdenu (Yalkhult on Ps. $\left.110 \int 869\right) .{ }^{90}$ Here the story of the staff begins with Judah, who passed it on to Tamar, then God gave it to Moses, who gave it to Aaron; eventually it came to David, who used it to slay Goliath. Subsequent kings continued to use the staff as a scepter, but it was lost in the destruction of the temple. It is said, however, that it will be given to the Messiah when he comes. Solomon of Basra (Book of the Bee 30) continues the providential transmission of the staff into Christian times. He says Phineas hid the staff in the desert until

robe, tradition claims, was bequeathed to the city by Helena, who found it in 327 or 328 along with the True Cross.

${ }^{88}$ Jacobus de Voragine, compiler of The Golden Legend: Readings on the Saints (2 vols.; trans. William Granger Ryan; Princeton: Princeton University Press, 1993), recounts some of these variants (1:277-78).

${ }^{89}$ The story begins with the legend of the "Quest for the Oil of Mercy" (Seth's efforts to retrieve the Oil from the Tree of Life and the angel's refusal) recounted in the Life of Adam and Eve 40-43 (with further elements added in later recensions of the text) and Gos. Nic. (Recension B) 19. See Esther C. Quinn, The Quest of Seth for the Oil of Life (Chicago: University of Chicago Press, 1962). For the Quest of Seth's elaboration in medieval legends of the True Cross, see Meyer, "Geschichte des Kreuzholzes vor Christus." The story is also found in Godfrey of Viterbo's Pantheon and the History of the Holy Rood Tree, a text that incorporates another account of the thirty silver pieces (mentioned above).

90 The examples here are discussed in Louis Ginzberg, "Aaron's Rod," JE 1 (1901) 5-6. 
God showed it to Joseph, who used it on his journey to Egypt and the return to Nazareth. The staff was passed on to James and Judas stole it. It was then used for the crossbeam of the cross. Solomon also briefly traces the origins of the purple cloak, mentioned just prior to the story from Leg. Silv. in Book of the Bee 44. The cloak is said to have been given to the Maccabees by the "emperors of the Greeks." The priests used it to dress the temple and later took it down and draped it around Jesus for his humiliation.

The best that can be said about the origins and transmission of Leg. Silv. is that, likely, it was composed around the fourth or fifth century, perhaps in Greek. The text then journeyed, through either oral or written transmission, to the West, where it was translated into Latin and then into European languages, and to the East, where it was translated into Syriac, Arabic (Garšūnī), and Armenian. No matter what its origins, it is a text that was valued throughout the Christian world, offering its readers answers to questions raised by the gaps in the Gospel record, supplying owners of Judas-penny relics a story of the origins of their prized possessions, and providing reassurance that the betrayal and death of Jesus was the result of a carefully-executed divine plan.

\section{TEXTS AND TRANSLATIONS}

Four separate texts and translations follow. The first two summarize the evidence for the West Syriac and East Syriac traditions. The West Syriac text is based on Ms A-Paris, Bibliothèque nationale, Syr. 197-chosen because it suffers from fewer errors and omissions than the other manuscripts. The East Syriac text is based on Ms M-London, British Library, Syriac 9chosen, again, because it has fewer scribal errors and deficiencies. On rare occasions, readings from other manuscripts have been adopted where the base manuscripts are clearly inferior. Readings from the Armenian tradition appear in the notes to WSyr. The Syriac editions were prepared by Tony Burke and Slavomír Ćéplö. The second pair of editions present the Garšunn̄ manuscripts, divided into two recensions: Garšunī A (utilizing RSTU and Y) and Garšunī B (consisting solely of V). The Garšūnī editions were prepared by Slavomír Céplö. Diacritics and vowels are not retained in the editions, nor for other manuscripts in the apparatus, unless they can affect meaning. The original punctuation also has not been retained, nor have abbreviations. 


\section{Sigla}

WSyr West Syriac recension
A: Paris, Bibliothèque nationale, Fonds Syriaque 197
B: Paris, Bibliothèque nationale, Fonds Syriaque 215
C: Birmingham, Mingana Syr. 480
D: Birmingham, Mingana Syr. 71
E: Birmingham, Mingana Syr. 369

ESyr East Syriac recension

M: London, British Library, Syriac 9

$\mathrm{N}$ : Berlin, Staatsbibliothek zu Berlin, Syr. 74

O: Paris, Bibliothèque nationale, Fonds Syriaque 309

P: Solomon of Basra, The Book of the Bee (edition E.

A. W. Budge based on $\mathrm{Pa}, \mathrm{Pb}^{\mathrm{b}}$, and $\mathrm{P}^{\mathrm{c}}$ )

Pa: London, Royal Asiatic Society, Syr. 1

Pb: London, British Library, Add. 25875

Pc: Munich, Bayerische Staatsbibliothek, Cod. Syr. 7

GarA Garšūnī recension A

R: Cambridge, Syriac Add. 2881

S: Birmingham, Mingana Syr. 22

T: Birmingham, Mingana Syr. 48

U: Birmigham, Mingana Syr. 479

Y: Mardin, Dayr Al-Zafaran 240

GarB Garšūn̄i recension B based on V: Birmigham, Mingana Syr. 514

Arm Armenian translation from Outtier, "Une forme enrichie," 140-43.

\section{BIBLIOGRAPHY}

Academia Caesarea Vindobonensis. Tabulae codicum manu scriptorum praeter Graecos et orientales in Bibliotheca palatina Vindobonensi asservatorum, Volumen 1, Cod. 1-2000. Vienna: Gerold, 1864.

Anasian, H. S. Bibliologie arménienne. Vol. 1. Erévan: Académie des Sciences, 1959. 
Assemani, Stefano Evodio. Bibliothecae Apostolicae Vaticane Codicum Manuscriptorum catalogus, Vol. 2, Codices Chaldaicos sive Syriacos. 1758; reprint, Paris: Maissoneuve, 1926.

Aumer, Joseph. Verzeichniß der orientalischen Handschriften der K. Hofund Staatsbibliothek in München, mit Ausschluß der hebraeischen, arabischen und persischen. 1875; reprint, Wiesbaden: Otto Harrassowitz, 1970.

Behland, Max. Die Dreikönigslegende des Johannes von Hildesheim. Munich: W. Fink, 1968.

Bezold, Carl. Kebra Nagast, die Herrlichkeit der Könige. Munich: Verlag der Könglichen Bayerischen Akademie der Wissenschaften, 1905.

Briquel-Chatonnet, Françoise. Manuscrits syriaques de la Bibliothèque nationale de France (nos 356-435, entrés depuis 1911), de la bibliothèque Méjanes d'Aix-en-Provence, de la bibliothèque municipale de Lyon et de la bibliothèque nationale et universitaire de Strasbourg. Paris: Bibliothèque nationale, 1997.

Budge, Ernest A. W., ed. The Book of the Bee: The Syriac Text Edited from the Manuscripts in London, Oxford, Munich, with an English Translation. Anecdota Oxoniensia, Semitic Series 1 part 2. Oxford: Clarendon Press, 1886. . The History of the Blessed Virgin Mary and the History of the Likeness of Christ. 2 vols. London: Luzac \& Co., 1899. . The Queen of Sheba and Her Only Son Menyelek. London: Martin Hopkinson \& Co., 1922.

Burke, Tony. "The Infancy Gospel of Thomas from an Unpublished Syriac Manuscript. Introduction, Text, Translation, and Notes." Hugoye 16.2 (2013): 225-99.

Chabot, Jean Baptiste. "Notice sur les manuscrits syriaques de la Bibliothèque Nationale." JA IXe série, 8 (Sept.-Oct. 1896): 234-90.

Cherchi, Paolo. "A Legend from St Bartholomew's Gospel in the Twelfth Century.” RB 91 (1984): 212-18.

Chipke, Renate and Kurt Heydeck. Handschriftencensus der kleineren Sammlungen in den östlichen Bundesländern Deutschlands: 
Bestandsaufnahme der ehemaligen Arbeitsstelle "Zentralinventar Mittelalterlicher Handscbriften bis 1500 in den Sammlungen der DDR" (ZIH). Wiesbaden: Harrassowitz, 2000.

Clemons, James T. "A Checklist of Syriac Manuscripts in the United States and Canada." OCP 32 (1966): 224-51, 478-522.

Creizenach, Wilhelm. Judas Ischarioth in Legende und Sage des Mittelalters, Separatabdruck aus den Beiträgen zur Geschichte der Deutschen Sprache und Literatur. Band II, Heft 2. Halle, Lippert'sche Buchhandlung, 1875.

de Lagarde, Paul. Praetermissorum libri duo. Göttingen: Officina Academica Dieterichiana, 1879.

de Mély, Fernand. "Les Deniers de Judas dans la Tradition du Moyen Âge.” Revue Numismatique 4.3 (1899): 500-509.

de Navaria (Obicino), Tommaso. Thesaurus arabico-syro-latinus. Rome: Sac. Congregationis de propag. Fide, 1636.

de Voragine, Jacobus. The Golden Legend: Readings on the Saints. Translated by William Granger Ryan. 2 vols. Princeton: Princeton University Press, 1993.

Deycks, Ferdinand, ed. Ludolphi, rectoris ecclesiae parochilais in Suchem, De itnere terrae Sanctae Liber. Bibliothek des Litterarischen Vereins in Stuttgart 25. Stuttgart: Literarischer Verein, 1851.

Desreumaux, Alain. Répertoire des bibliothèques et des catalogues de manuscrits syriaques. Documents, études et répertoires publiés par l'Institut de recherché et d'histoire des texts. Paris: Éditions du CNR, 1991.

Drijvers, Jan Willem. Helena Augusta: The Mother of Constantine the Great and the Legend of Her Finding of the True Cross. Leiden/New York: Brill, 1992.

du Méril, Edélestand, ed. Poésies populaires latines du Moyen Age. Paris: Firmin Didot \& A. Franck, 1847.

Furlani, Giuseppe. "Il manoscritto siriaco 9 dell'India Office." RSO 10 (1923-1925): 315-20. 
Ginzberg, Louis. "Aaron's Rod." In vol. 1 of The Jewish Encyclopedia. Edited by Isidore Singer et al., 5-6. New York: Funk \& Wagnalls, 1901.

Godfrey of Viterbo. Pantheon, sive Vniversitatis Libri, qui Chronici appellantur. Basel: ex officina Iocabi Parci, 1559.

Graf, George. Geschichte der christlichen arabischen Literatur. Vol. 1. Vatican City: Biblioteca Apostolica Vaticana, 1944.

Gretser, Jakob. Hortus Sanctae Crucis. Ingolstadt, 1610.

Harris, Sylvia C. "German translations of the Historia Trium Regum by Johannes de Hildesheim." Modern Language Review 53 (1958): 364-73.

. "The Historia Trium Regum and the Mediaeval Legend of the Magi in Germany." Medium aevum 28 (1959): 23-30.

Hassler, Cunradus D., ed. Evagatorium in Terrae Sanctae, Arabia et Egypti peregrinationem, Fratris Felicis Fabri. Vol. 1. Stuttgart: Sumptibus Societatis Litterariae, 1843.

Hill, George Francis. "The Thirty Pieces of Silver." Archaeologica 59 (1905): 235-54. Reprint in idem, The Medallic Portraits of Christ, The False Shekels, The Thirty Pieces of Silver. Oxford: Clarendon Press, 1920, 91-116.

Hofmann, Rudolph. A. Das Leben Jesu nach den Apokryphen im Zusammenhang aus den Quellen erzäblt und wissenschaftlich untersucht. Leipzig: Friedrich Voigt, 1851.

Hook, David. "The Legend of the Thirty Pieces of Silver." In The Medieval Mind: Hispanic Studies in Honour of Alan Deyermond. Edited by Ian R. MacPherson and Ralph J. Penny, 205-21. London: Tamesis, 1997.

Horstman, Carl, ed. The Three Kings of Cologne: An Early English Translation of the 'Historia Trium Regum' by John of Hildesheim. EETS, Old Series 85. London: Oxford University Press, 1886.

Jullien, Florence. "La légende des Trente pièces d'argent de Judas et le roi Abgar.” Apocrypha 24 (2013): 207-20.

Kane, Thomas L. "An Amharic Version of the Origin of the Cross." BSAOS 44.2 (1981): 273-89. 
Köpke, Ernst. Mittheilungen aus den Handschriften der Ritter-Akademie zu Brandenburg A.H., Vol. 1, Johannes von Hildesheim. Brandenburg: G. Matthes, 1878.

Macomber, William F. Final Inventory of the Microfilmed Manuscripts of the Coptic Museum Old Cairo, Egypt. Provo, Utah: Brigham Young University, 1995.

Margoliouth, George. Descriptive List of Syriac and Karshuni MSS. in the British Museum Acquired since 1873. London: Longmans \& Co., 1899.

Meyer, Wilhelm. "Die Geschichte des Kreuzholzes vor Christus." Abhandlungen der philosophisch-philologischen Classe der Königlich Bayerischen Akademie der Wissenschaften 16 (1882): 103-66.

Mingana, Alphonse. Woodbrooke Studies: Christian Documents in Syriac, Arabic, and Garshuni. 3 vols. Cambridge: Cambridge University Press, 1927-1931.

. Catalogue of the Mingana Collection of Manuscripts. Vol. 1. Cambridge: W. Heffer \& Sons, Ltd., 1933.

Napier, Arthur S. History of the Holy Rood-tree. EETS, Old Series 103. London: Oxford University Press, 1894.

Nau, François. "La version syriaque de la vision de Théophile sur le séjour de la Vierge en Egypte." ROC 15 (1910): 125-32.

- "Notice des manuscrits syriacques entrés à la Bibliothèque Nationale de paris depuis l'édition des catalogues (syriacques 289-355)." ROC 16 (1911): 271-323.

Outtier, Bernard. "Une forme enrichie de la Légended'Abgar en arménien." In Apocryphes arménians: transmission-traductioncreation-iconographie; Acts du colloque international sur la littérature apocryphe en langue arménienne (Genève, 18-20 septembre 1997). Edited by in Valentina Calzolari Bouvier, Jean-Daneil Kaestli, and Bernard Outtier, 129-45. Lausanne: Éditions du Zébre, 1999.

Paffenroth, Kim. Judas: Images of the Lost Disciple. Louisville, Ky.: Westminster/John Knox, 2001.

Pasha, Marcus Simaika and Yassa Abd al-Masih Effendi. Catalogue of the Coptic and Arabic Manuscripts in the Coptic Museum, the 
Patriarchate, the Principal Churches of Cairo and Alexandria and the Monasteries of Egypt in 3 Volumes. Vol. 1. Cairo: Government Press, 1939.

Pertsch, Wilhelm. Die orientalischen Handschriften der Herzoglichen Bibliothek zu Gotha. Gotha: Friedr. Andr. Perthes, 1893.

Quinn, Esther C. The Quest of Seth for the Oil of Life. Chicago: University of Chicago Press, 1962.

Reiner, Erica. “Thirty Pieces of Silver.” JAOS 88.1 (1968): 186-90.

Sachau, Eduard. Verzeichniss der syrischen Handschriften der Königlichen Bibliothek. Erste Abtheilung. Berlin: A. Asher \& Co., 1899.

Sarau, Kashisha Oshana and Shedd, John H. Catalogue of Syriac Manuscripts in the Library of the Museum Association of Oroomiah College. Urmiah: Library of the Museum Association of Oroomiah College, 1898.

Schneider, Bernard. "Holy Coat." In Religion Past and Present. Vol. 6. Edited by Hans Dieter Betz, Don S. Browning, Bernd Janowksi, and Eberhard Jüngel, 218-219. Leiden: Brill, 2009.

Schoenfelder, J. M. Salomonis, episcope Bassorensis, liber apis, syriacum arabicumque textum latine. Bamberg: O. Reindl, 1866.

Smith, Robert Payne. Catalogi Codicum Manuscriptorum Bibliothecae Bodleianae. Pars sexta. Oxford: Bodleian Library, 1864.

Société de l'école des Chartres. Bibliothèque de l'École des chartres. Revue d'érudition consacrée specialement a l'étude du moyen age. Vol. 53. Paris: Libraire d'Alphonse Picard, 1892.

Stewart, Aubrey, trans. Book of the $W$ anderings of Brother Felix Fabri. 4 vols. Palestine Pilgrims' Text Society 7-10. London: 24 Hanover Square W., 1893-1896.

. Ludolph von Suchem's Description of the Holy Land, and of the Way Thither, Written in the Year AD 1350. Palestine Pilgrims' Text Society 12. London: Palestine Pilgrims' Text Society, 1895.

Trustees of the British Museum. Catalogue of the Additions to the Manuscripts of the British Museum 1888-1893. London: British Museum, 1894. 
Wright, William. Apocryphal Acts of the Apostles, Edited from Syriac manuscripts in the British Museum and Other Libraries, Vol. 1, The Syriac Texts. London: Williams and Norgate, 1871.

. Catalogue of the Syriac Manuscripts in the British Museum Acquired since the Year 1838. Part 3. London: Longmans \& Co., 1872.

. Catalogue of the Syriac Manuscripts in the Library of the University of Cambridge. Vol. 2. London: C. J. Clay and Sons, 1901.

Zotenberg, Hermann. Catalogues des manuscrits syriaques et sabéens (mandad'tes) de la Bibliothèque nationale. Paris: Imprimerie nationale, 1874. 
Syriac Tradition of the Thirty Pieces of Silver

[page left blank intentionally] 


\title{
West Syriac Recension
}

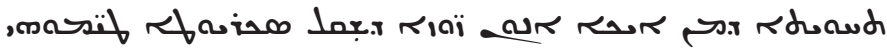

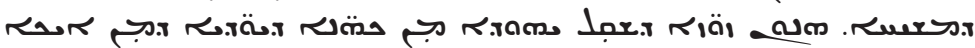 \\ amoir madur nasa ars \\ 1

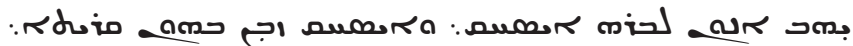

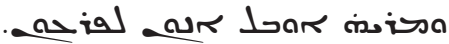

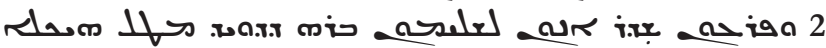

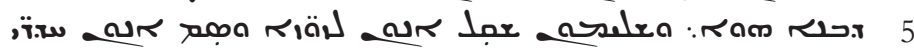

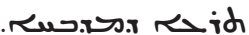

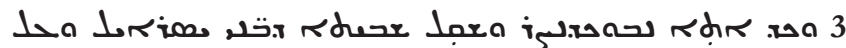

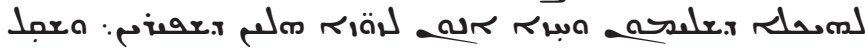

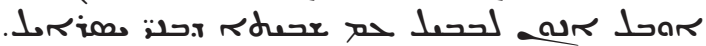

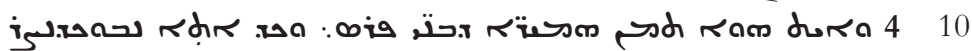

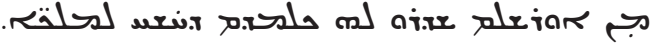

\section{ABCDE}

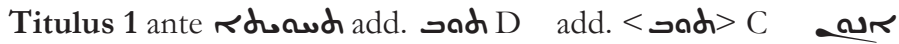

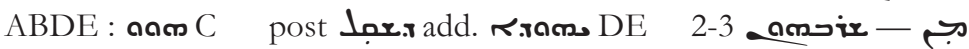
$\mathrm{ABC}: \mathrm{om} . \mathrm{DE}$

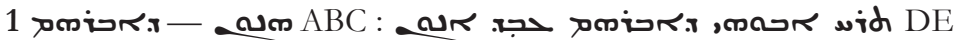

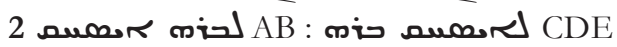

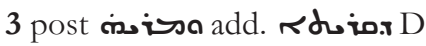

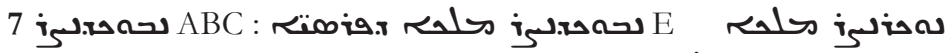
:

1rim $\mathrm{BC}$

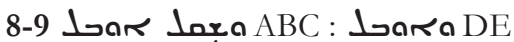

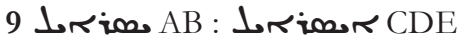

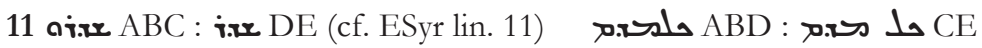




\section{East Syriac Recension}

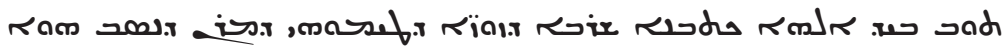

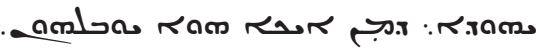

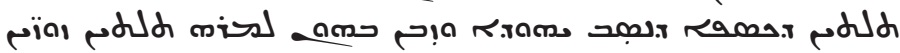

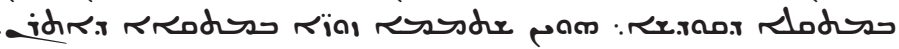

1

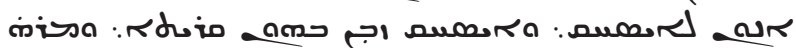

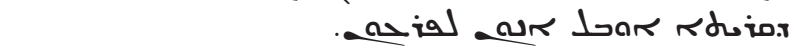
2

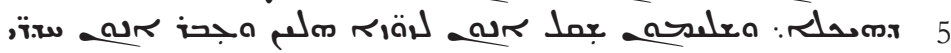

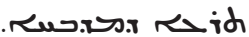

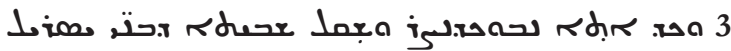

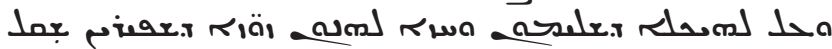

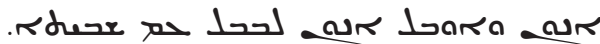

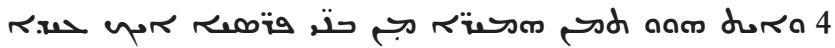

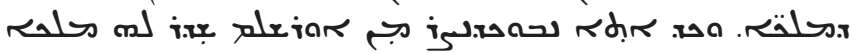

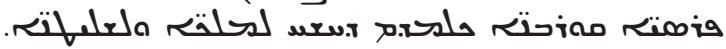

MNOP

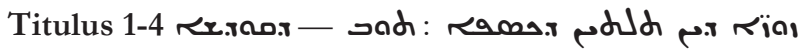
ram. Pb]

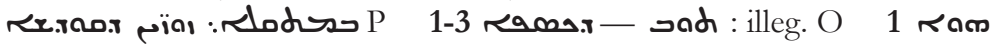

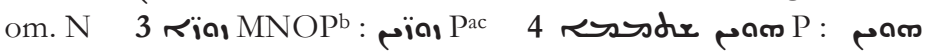

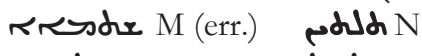

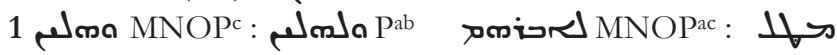

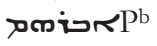

5 مسلع MOP Pc om. N

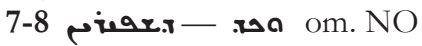

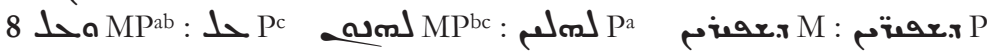

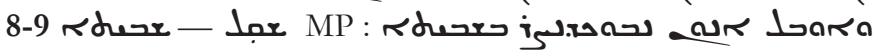
معل O] NO

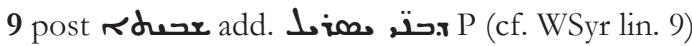

10 אדק MNO MNO : om. P

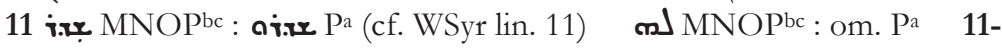

12 sNO : om. P (cf. WSyr lin. 7 DE)

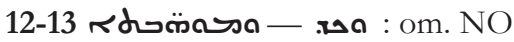




\section{West Syriac Recension}

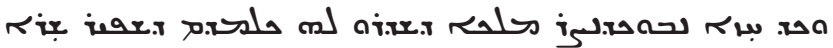

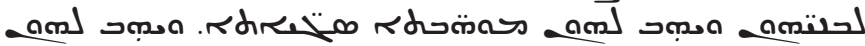

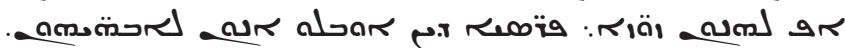

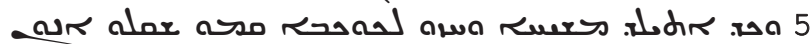
א

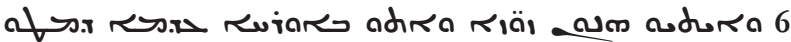

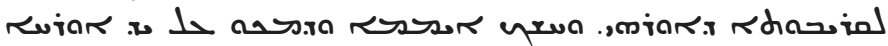

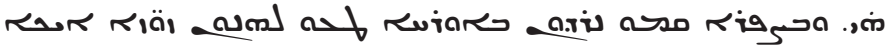

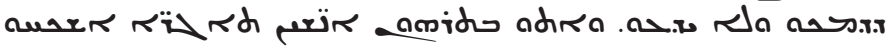
राव̈ل 20

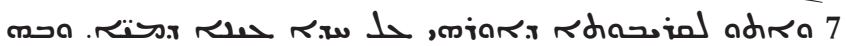

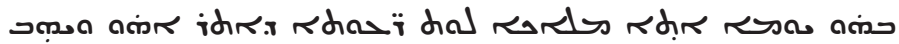

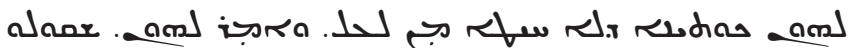

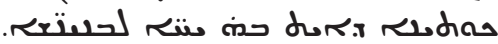
25 له

\footnotetext{
ABCDE

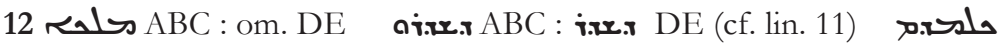
ABDE : حل ת C $\mathrm{C}$

14 ra CDE (cf. ESyr lin. 14) : مجم AB (err.)

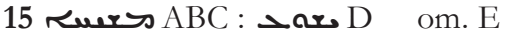

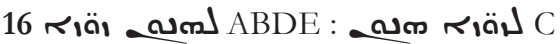

17 مा $\mathrm{ABC}$ :

18 אתדבת : DABCDpcE

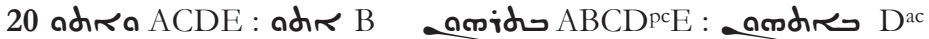

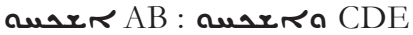

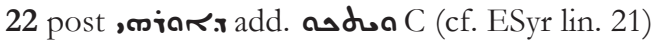

24-25 r. ACDE : om. B (homoeotel.)

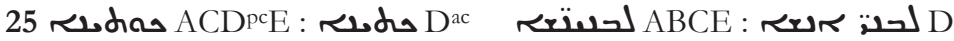

27 a a
} 


\section{East Syriac Recension}

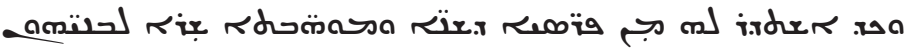

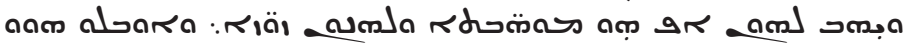

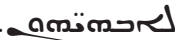

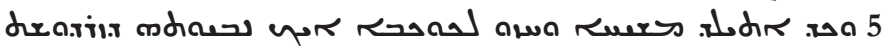

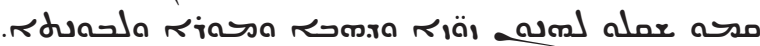
6

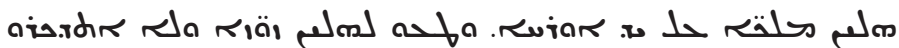

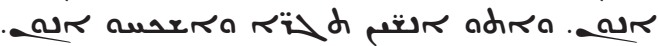
adro 7

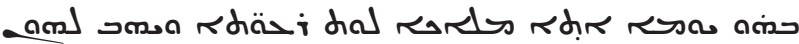

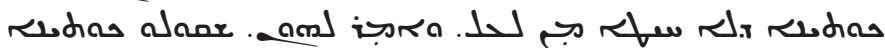

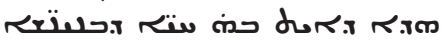
8 a 8 are

MNOP

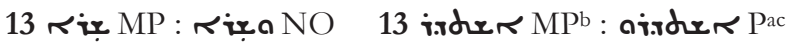

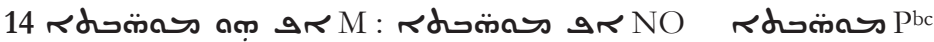

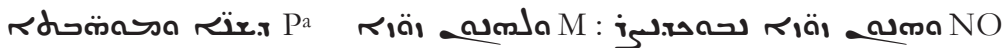

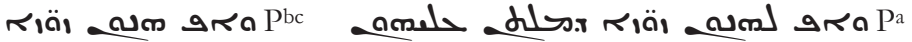
a ars مra دarano

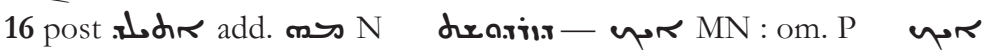
dra $\mathrm{O}$

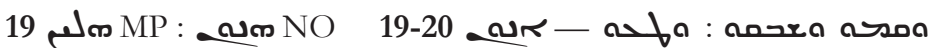

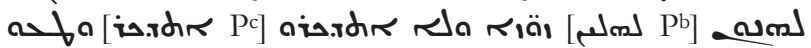

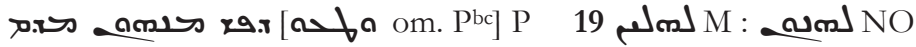

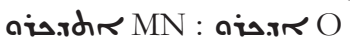

20 post alt. مكمله مאد مו̈, $\mathrm{Pbc}$

21 a a MPa : a مra NO om. Pbc

22 post حصم $\mathrm{O}$ (et expunxit)

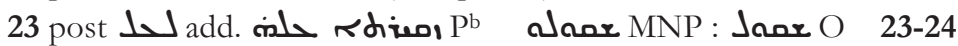

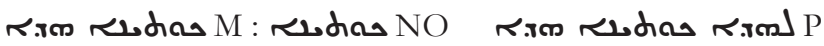

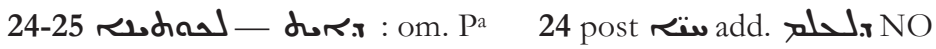

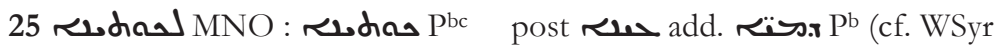
lin. 26) 25-26 حلم حسم : MOP : transp. N 


\section{West Syriac Recension}

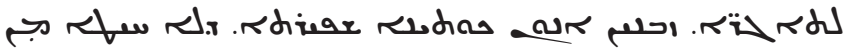
لע.

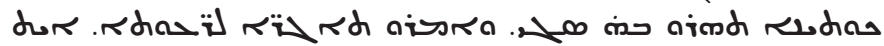

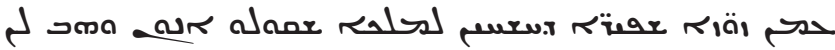
30

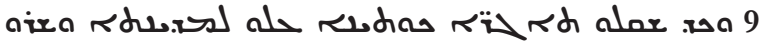
dor.

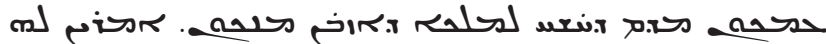

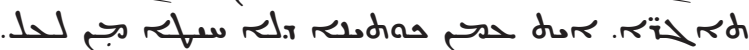

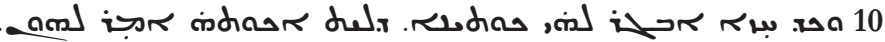

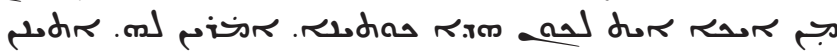

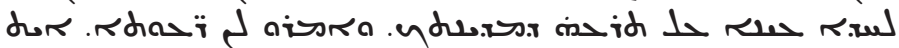

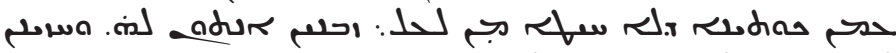

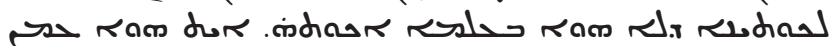

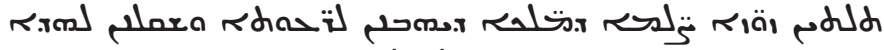

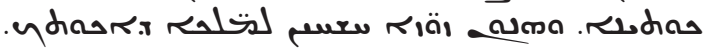

\footnotetext{
ABCDE

28 م A A adur BCDE Rar ABC: om. DE

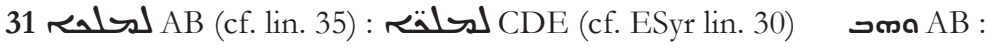

ه

33 حله $\mathrm{C}$

38 ro AB : om. CDE

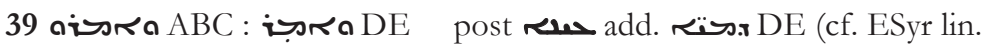

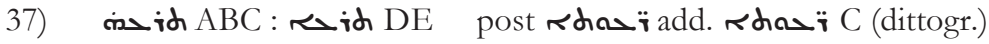

40 adur $\mathrm{ABC}$ : om. DE

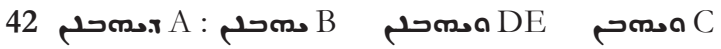

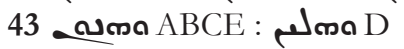




\section{East Syriac Recension}

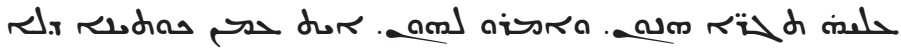

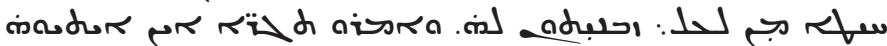
m.

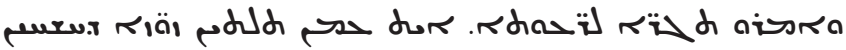

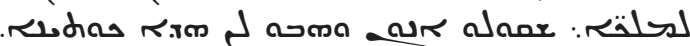

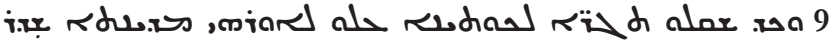
sol

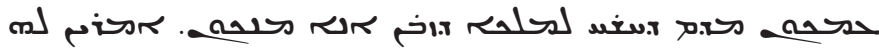

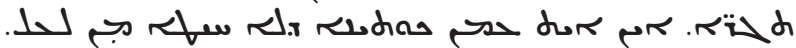

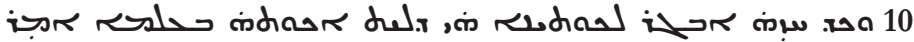

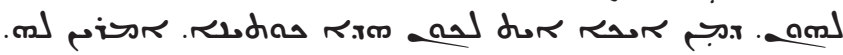

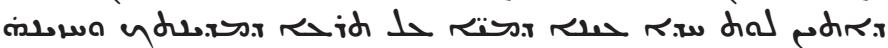

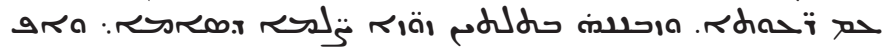
ח

\footnotetext{
MNOP

26 لم P : sup. lin. M om. NO

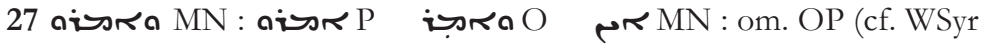
lin. 29)

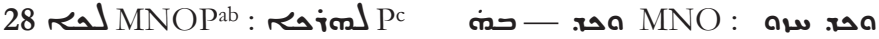

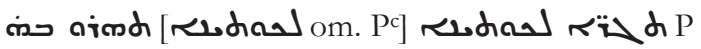

29 r لتحمNOPc: om. Pab

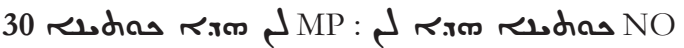

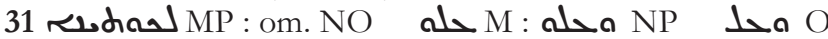

32 هـ $32 \mathrm{MPb}$ : $\mathrm{PO}$ ला MNO : om. P

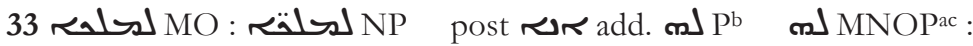
om. $\mathrm{Pb}$

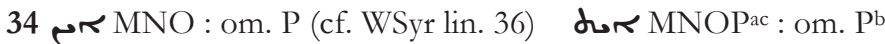

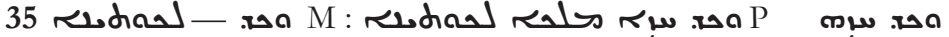

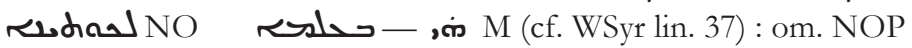

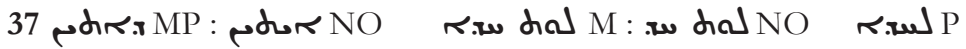

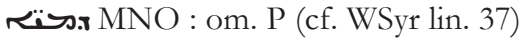

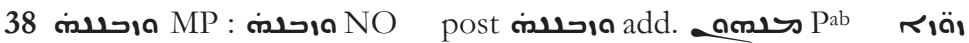
MNOPab : ובוم Pc
} 


\section{West Syriac Recension}

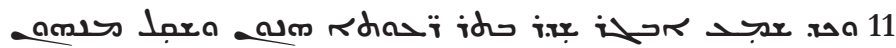

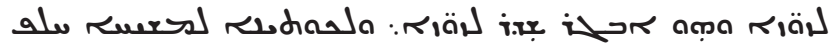

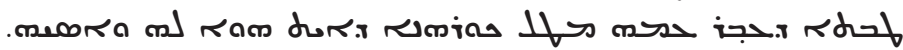

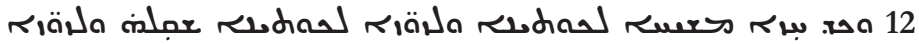

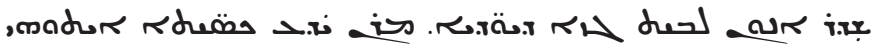

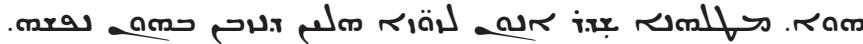

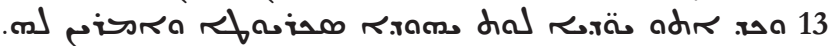
א.

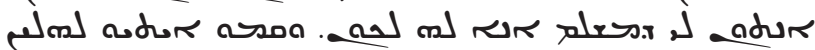

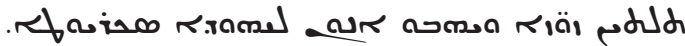

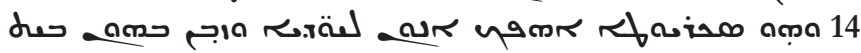

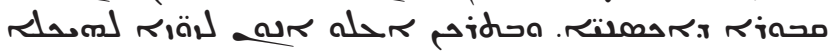

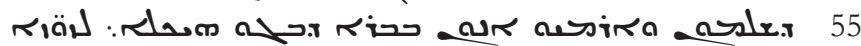

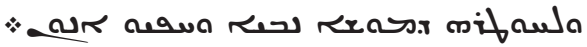

ABCDE

44 aمب ABCD : عمله E (cf. ESyr. lin. 40 NOPa)

45 post צ्. add.

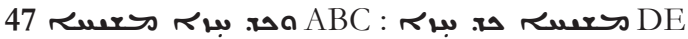

48 post radd.

ABDE : aக் $C$

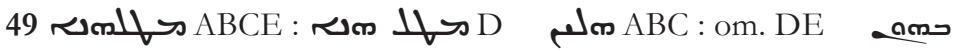
ABCE : له D D D

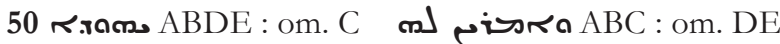

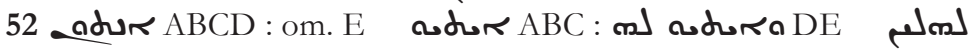
ABC : لمس DE

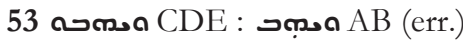

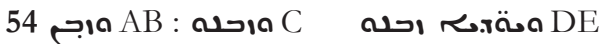

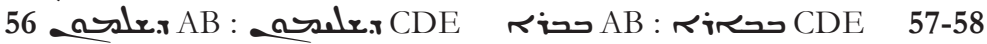

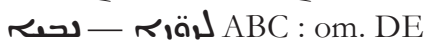

57 post r.add. 


\section{East Syriac Recension}

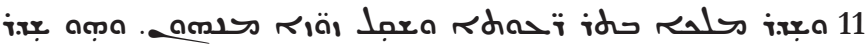

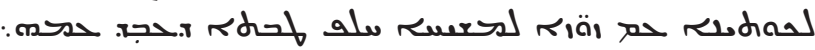

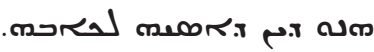

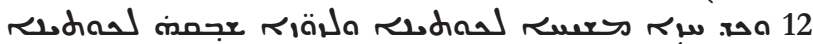

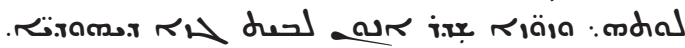
13

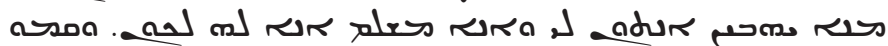

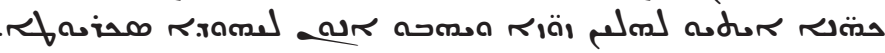
14 مص: adidr,

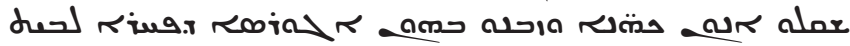

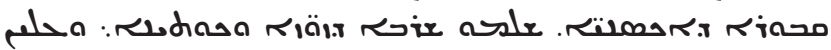
50

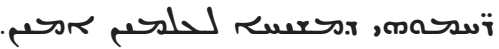

\section{MNOP}

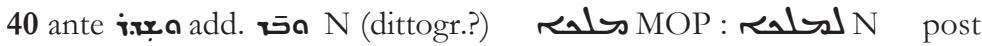

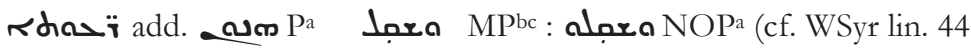

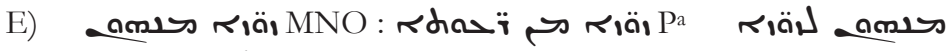

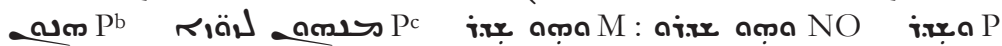

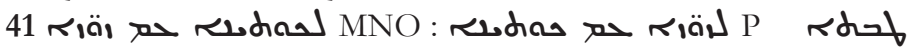

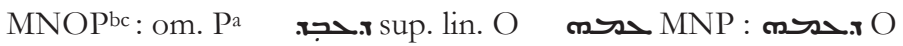

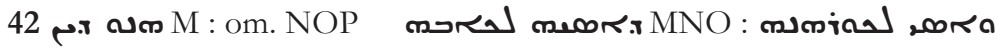
$\mathrm{P}$

43 riäla MNP : om. O 43-44 mdal rada MNP : om. O

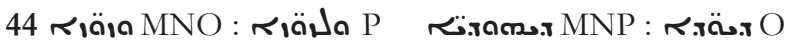
45 post daل add. ت̈ $\mathrm{Pb}$

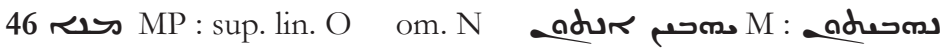

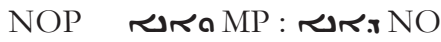

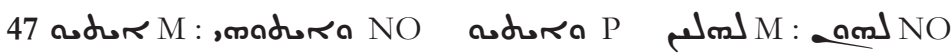

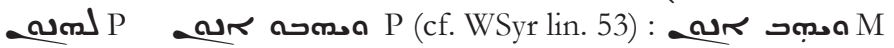

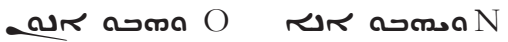

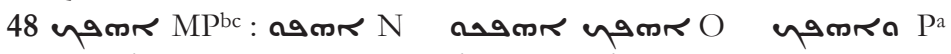

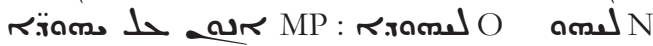

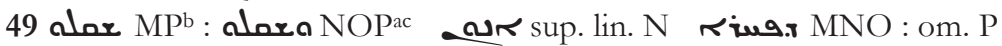

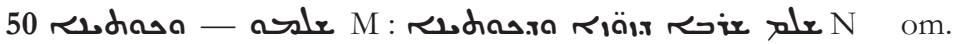

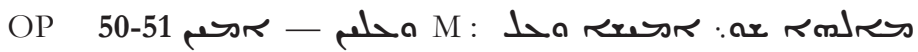

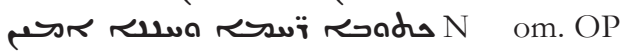




\section{West Syriac Recension}

\section{A demonstration of the origin of those pieces which Iscariot ${ }^{1}$ received as the price of Christ, those pieces which Judas received from the Jewish priests, where are they from and what is their story?}

1 Terah, the father of Abraham made those pieces. Abraham gave them to his son Isaac. And Isaac bought a village with them. ${ }^{3}$ The master of it ${ }^{4}$ brought them to Pharaoh.

2 Pharaoh sent them to Solomon, the son of David, for the temple he was building. And Solomon took the pieces and placed them around the door of the altar.

3 When Nebuchadnezzar ${ }^{5}$ came and took captive the children of Israel, he entered the temple of Solomon and saw that the pieces were beautiful, ${ }^{6}$ and he took and brought them ${ }^{7}$ to Babylon with the captive children of Israel.

4 And there were some Persians there as hostages. When Nebuchadnezzar came from Jerusalem, they sent ${ }^{8}$ him everything fit for kings.

\footnotetext{
1 "Judas Iscariot" in DE.
}

${ }^{2}$ DE lack "where are they from and what is their story?"

${ }^{3}$ In Arm, Terah uses the money to buy "the cave with the son of Amor." Presumably this is Abraham's burial cave from Gen 23, which was purchased from Ephron the Hittite for 400 shekels of silver. The burial cave appears also in John of Hildesheim and related Latin Mss. From here, like the Latin tradition, Arm moves right to the story of Joseph: "The Edessenians took the money and bought Joseph from his brothers. And the brothers of Joseph brought it as a gift to Joseph in Egypt."

${ }^{4} \mathrm{D}$ has "master of the village" (cf. ESyr).

${ }^{5} \mathrm{DE}$ add "king of the Persians" (cf. GarAB) an incorrect designation, as Nebuchadnezzar was the king of Babylon, not Persia.

${ }^{6} \mathrm{DE}$ lack "children of Israel" to "beautiful," perhaps due to parablepsis.

${ }^{7}$ DE have just "and he brought them."

${ }^{8}$ DE have "he sent" (cf. ESyr MNO). "They" likely refers here to the Persian rulers seeking to regain the hostages. This identification is made explicit in ESyr with its mention of the "king of the Persians" in this context. 


\section{East Syriac Recension}

And so, with God's help, the tale of the pieces which Judas accepted for the price of our Lord, what is the history of their transmission??

The thirty (pieces) of silver which Judas accepted and for which he sold his Lord, were thirty pieces according to the weight of the sanctuary. These were equal to six hundred pieces according to the weight of our country. ${ }^{10}$

1 Terah made these pieces for his son Abraham. Abraham gave them to Isaac. And Isaac bought a village with them. The master of the village brought them to Pharaoh.

2 Pharaoh sent them to Solomon, the son of David, for the building of the temple. And Solomon took these pieces and put them around the door of the altar.

3 When Nebuchadnezzar came and took captive the children of Israel, he entered the temple of Solomon and saw that these pieces were beautiful, ${ }^{11}$ and he took them and brought them ${ }^{12}$ to Babylon with the captives. ${ }^{13}$

4 And there were some Persians there as hostages, according to the custom of the kings. ${ }^{14}$ When Nebuchadnezzar came from Jerusalem, the king of the Persians sent offerings, ${ }^{15}$ everything fit for kings and rulers.

${ }^{9}$ Much of the title is illegible in O.

10 This prologue varies slightly in the witnesses. NO shorten the description of the currency to "were thirty pieces according to the weight of out country"; P to "were equal to six hundred pieces according to the weight of our country."

${ }^{11} \mathrm{NO}$ lack this sentence.

12 NO have "And Nebuchadnezzar brought them."

13 P has "captive children of Israel" (cf. WSyr)

14 P lacks "according to the custom of the kings."

${ }^{15} \mathrm{P}$ has only "they sent offerings." 


\section{West Syriac Recension}

And when king ${ }^{16}$ Nebuchadnezzar saw that everything they had sent ${ }^{17}$ him was beautiful, he released their sons and gave them many presents. He gave them also those pieces. And the Persians brought $^{18}$ them to their fathers.

5 When Christ $^{19}$ was born and they saw the star, they rose and took those pieces and gold and myrrh and frankincense.

6 They brought those pieces and traveled on the road until they reached the vicinity of Edessa. The day grew dark and they fell asleep on the side of the road. In the morning they arose to continue on the road. They forgot those pieces where they slept and did not know (it). Some merchants came after them and found the pieces.

7 They came to the vicinity of Edessa ${ }^{20}$ by a certain well. And on that very day an angel came to the shepherds of that land and he gave them a robe without a seam on the upper end. And he said to them, "Take the robe ${ }^{21}$ in which there is salvation for humanity."

8 The shepherds took the robe and came to a well. And they found the merchants who had found the pieces by the well of water. They said to the merchants, "Will you buy this beautiful22 robe without a seam at the upper end?" The merchants said, "Bring it here." And when the merchants saw this robe, they marveled at it very much. The merchants said to the shepherds, "We have beautiful pieces worthy of a king. Take them and give us this robe."

${ }^{16}$ DE lack "king."

${ }^{17} \mathrm{DE}$ has the singular (see note 6 above).

${ }^{18} \mathrm{AB}$ have the singular.

${ }^{19} \mathrm{D}$ has "Jesus"; E has "he."

${ }^{20} \mathrm{C}$ adds "and sat down" (cf. ESyr).

${ }^{21}$ B lacks "without... robe," perhaps due to homoeoteleuton.

${ }^{22}$ DE lack "beautiful." 


\section{East Syriac Recension}

And since gifts and presents had been sent ${ }^{23}$ by the Persians, ${ }^{24}$ he released their sons and ${ }^{25}$ also gave them presents and those pieces. ${ }^{26}$ And they brought (them) to their fathers.

5 When Christ was born and they saw the star (as in the prophecy of Zarathustra), ${ }^{27}$ they rose and took those pieces and gold and myrrh and frankincense.

6 They set forth on a road and came to the vicinity of Edessa. And these kings fell asleep on the side of the road. And they forgot these pieces and did not remember them. ${ }^{28}$ Some merchants came and found them. ${ }^{29}$

7 They came to the vicinity of Edessa, and sat down by a well. And on that very day an angel came to the shepherds, and he gave them a robe without a seam at the upper end. ${ }^{30}$ And he said to them, "Take this robe in which there is salvation ${ }^{31}$ for humanity."

8 The shepherds took the robe and came to a well ${ }^{32}$ where those merchants were. They said to them, ${ }^{33}$ "We have a robe without seam at the upper end; will you buy it?" And the merchants said, ${ }^{34}$ "Yes, ${ }^{35}$ bring it here." And when they brought ${ }^{36}$ the robe the merchants saw it and marveled at it. The merchants said to the shepherds: "We have thirty pieces worthy of kings. Take them and give us this robe."

${ }^{23} \mathrm{M}$ has the singular.

${ }^{24}$ NO lacks "And since...Persians."

${ }^{25} \mathrm{NO}$ add "Nebuchadnezzar."

${ }^{26} \mathrm{~Pa}^{\mathrm{a}}$ has "and also those pieces of which we have spoken."

27 The prophecy is not mentioned in P.

${ }^{28} \mathrm{P}$ is lengthier, approaching the reading in WSyr: "And they arose and left those pieces behind, and did not remember and forgot that anything of theirs remained."

${ }^{29} \mathrm{P}$ adds "and took those pieces."

$30 \mathrm{~Pa}$ adds "woven throughout."

${ }^{31}$ NO has "eternal salvation."

32 Pa has only "And they came to a well." Pb adds "of water" (cf. WSyr).

${ }^{33}$ NO lack "to them."

$34 \mathrm{P}$ adds "to them."

35 OP lack "yes" (cf. WSyr).

36 P lacks "when they brought." 


\section{West Syriac Recension}

9 When the merchants had taken the robe, they entered the city and stopped at an inn. Abgar the king sent for the merchants and said (to them), "Have you anything worthy of a king that I could buy from you?" The merchants said to him, "We have a robe without a seam at the upper end."

10 When Abgar saw that robe of which there was no equal, he said to them, "Where did you get this robe?" They said to him, "We came to a certain well by the gate of your city. And some shepherds said to us, "We have a robe without a seam at the upper end. Will you buy it?' And we saw a robe that has no equal in the world. We had with us thirty pieces stamped with images of kings which we gave to the shepherds and received this robe. And these pieces are worthy of kings such as yourself."

11 When Abgar heard this, he sent for the shepherds and took the pieces from them. And Abgar sent the pieces and the robe to Christ for the good that he had done him, for he healed his disease. ${ }^{37}$

12 When Christ saw the robe and the pieces, he took the robe and sent the pieces to the Jewish treasury. Our Lord knew their secrets. That is why he sent these pieces with which he would be bought.

${ }^{37}$ Arm summarizes vv. 2-11 as, "When Nebuchadnezzar deported Jerusalem, he broke the door and carried it to Babylon. The Babylonians gave it to the Chaldeans. The Chaldeans gave it to the merchants, and the merchants gave it to the shepherds. And Abgar, having received it from the shepherds gave it to us (i.e., Jesus and the apostles)." The merchants and shepherds are mentioned earlier in Arm (v. 5). In recounting Abgar's commissioning of Addai, the text details how the merchants appeared before Abgar in Edessa with the Seamless Robe and the purple cloak. The robe was purchased by the merchants from the shepherds who received it from angels. 


\section{East Syriac Recension}

9 When the merchants had taken the robe, 38 they entered the city of Edessa. Abgar sent to the merchants and said to them, "Have you anything worthy of a king that I could buy from you?" The merchants said to him, "Yes, ${ }^{39}$ we have a robe without a seam at the upper end."

10 When Abgar saw that robe of which there was no equal in the world, ${ }^{40}$ he said to them, "Where did you get this robe?" They said to him, "We came to a certain well by the gate of your city. And we saw it with some shepherds." And we bought it ${ }^{41}$ for thirty stamped pieces of silver. And these pieces too are worthy of kings such as yourself."

11 And the king sent for the shepherds, and received the pieces from them. And he sent the robe with the pieces to Christ for the good $^{42}$ that he had done him and (because) he cured his sickness.

12 When Christ saw the robe and the pieces ${ }^{43}$ he kept the robe to himself ${ }^{44}$ and sent the pieces to the Jewish treasury.

${ }^{38}$ NO lack "the robe."

39 P lacks "yes" (cf. WSyr).

40 Only M has "of which there was no equal in the world" (cf. WSyr). The other witnesses begin instead "and when he (P: the king) saw the robe"

41 pab add "from them."

42 Pa lacks "the good."

43 O lacks "the pieces."

${ }^{44} \mathrm{~N}$ has only "he took it." 


\section{West Syriac Recension}

13 And when the Jews ${ }^{45}$ came to Judas Iscariot they said to him, ${ }^{46}$ "Deliver to us Jesus, son of Joseph!" He said to them, "What will you give me if I deliver him to you?" And they rose (and) brought those thirty pieces and gave them to Judas Iscariot.

14 And Iscariot returned them to the Jews. They ${ }^{47}$ bought with them a burial-place for strangers. ${ }^{48}$ And then they brought the pieces to Solomon's temple and threw them into a fountain inside the temple-the pieces, as well as the staff of Moses the prophet ${ }^{49}$ —and thus hid them. ${ }^{50}$

${ }^{45} \mathrm{C}$ has "they."

${ }^{46}$ DE lack "they said to him."

${ }^{47}$ DE have "the Jews."

${ }^{48} \mathrm{In}$ Arm, like the Latin tradition, the priests give the money to the guards at the tomb, though in Arm the guards return it saying, "This money should not be kept, because it is the price of blood." So the priests buy the potter's field.

${ }^{49}$ DE lack "the pieces and the staff of Moses the prophet."

${ }^{50} \mathrm{DE}$ add "peace." 


\section{East Syriac Recension}

13 And when Judas Iscariot came to the priests, ${ }^{51}$ he said to them, "What will you give me if I deliver him to you?" And the priests rose (and) brought those pieces and gave them to Judas Iscariot.

14 And when he repented, he returned them to the Jews ${ }^{52}$ and went (and) hanged himself. The priests took them and bought with them a potter's ${ }^{53}$ field for a burial-place for strangers.

This completes the story of the pieces and the robe. ${ }^{44}$ May the mercy of Christ be on you forever, amen..$^{55}$

${ }^{51} \mathrm{~Pb}$ has "the chief priests."

${ }^{52} \mathrm{NO}$ have the erroneous "to Judas."

${ }^{53}$ P lacks "potter's."

54 This sentence is lacking in $\mathrm{O}$ and $\mathrm{P}$.

55 The final benediction is lacking in $\mathrm{O}$ and $\mathrm{P} ; \mathrm{N}$ has "And glory to God, amen. And on the scribe, mercy and grace, amen.” 


\section{Garšūnī A}

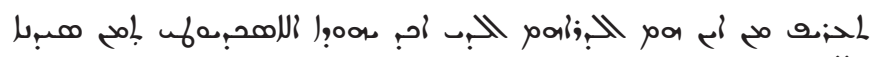
ا لمهس

1

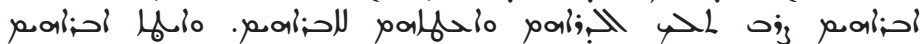
paro

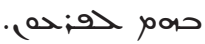

5

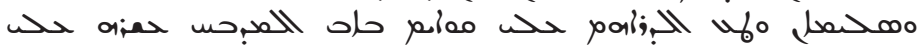

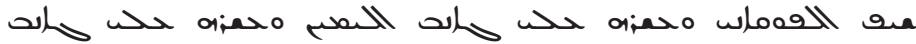
الحسماز.

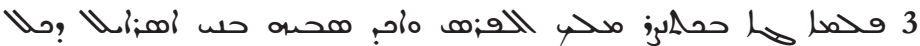

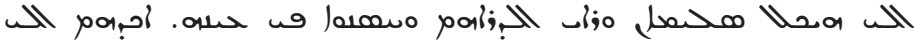

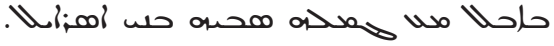

\section{RSTUY}

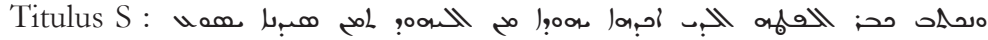

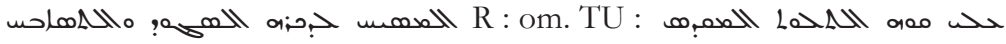

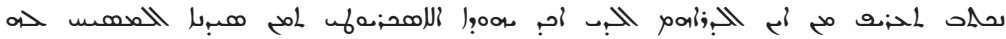
الحم

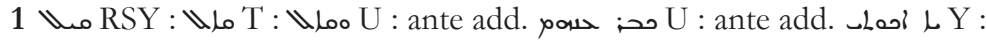

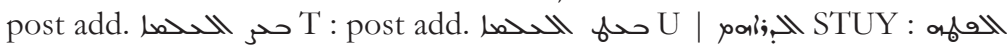

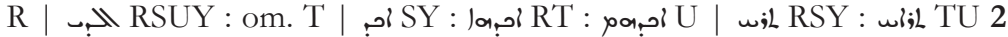
أحid RSUY : أح: T : post add. الحمحس : TUY |

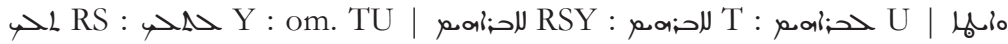

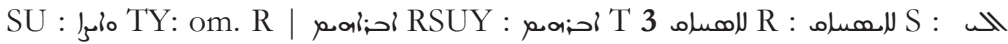

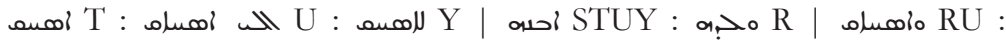

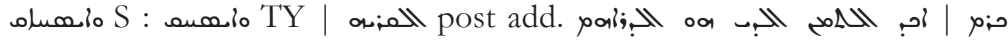

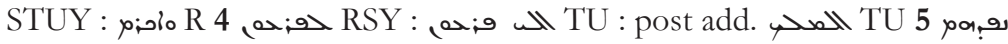

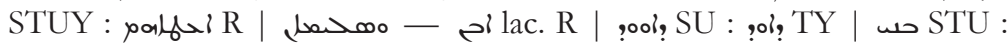

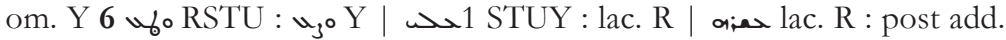

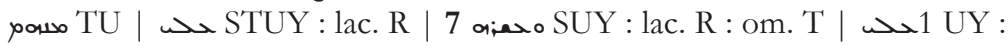

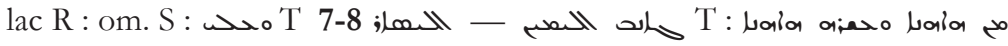

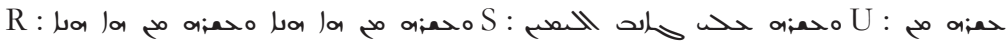

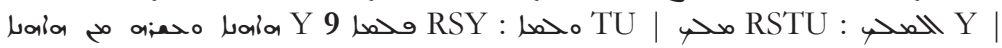

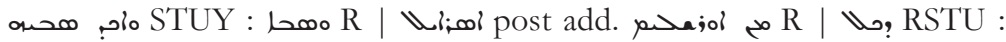

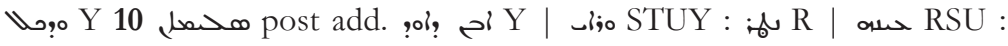

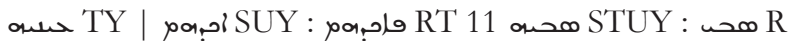




\section{Garšūnī B}

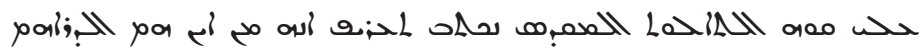

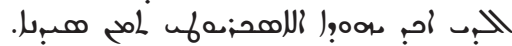

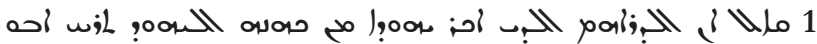

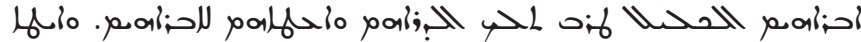

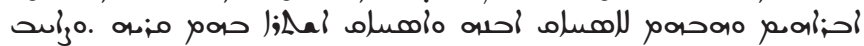
5

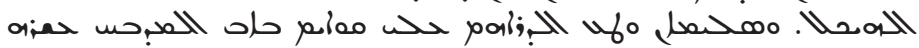

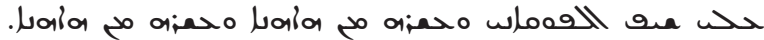

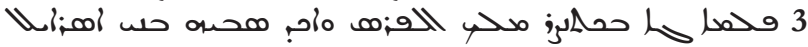
وملا الح a a 10 


\section{Garšūnī A}

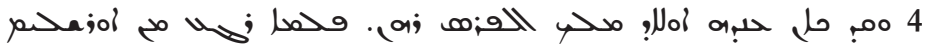
9901

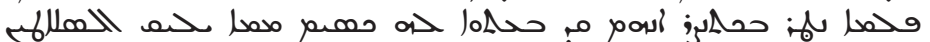
15

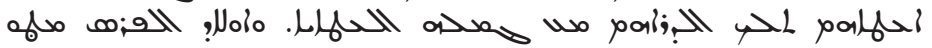

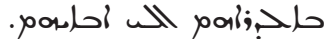

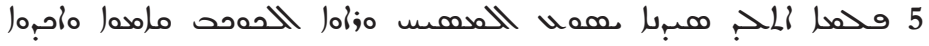
قس

20

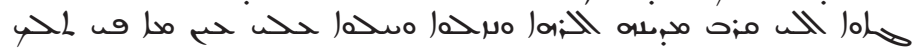

\section{RSTUY}

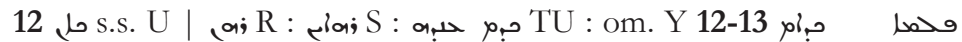

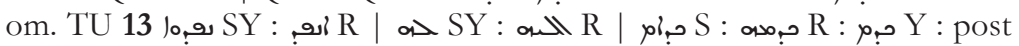

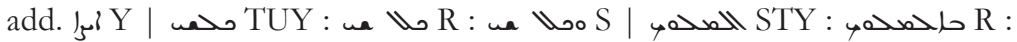

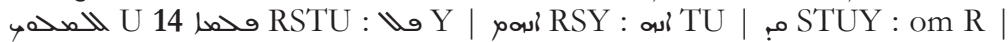

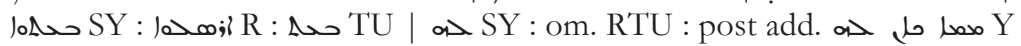

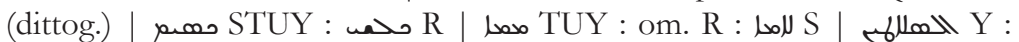

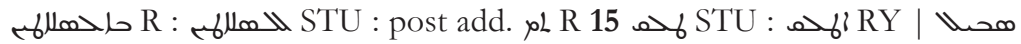

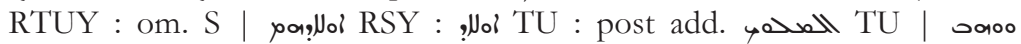

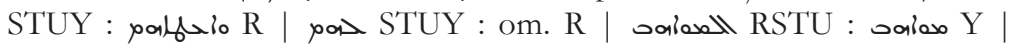
aish RSTU : ais $\mathrm{Y} \mid$ | رأ

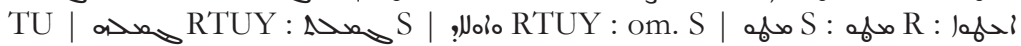

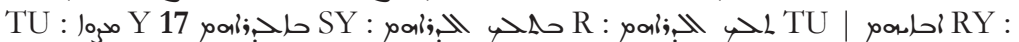

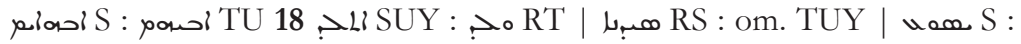

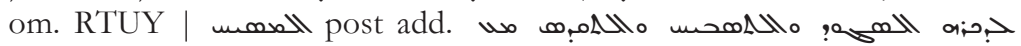

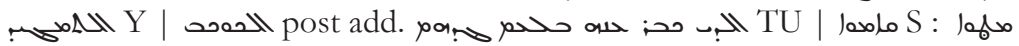

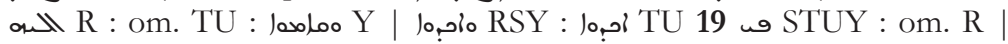

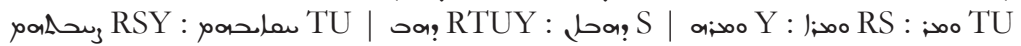

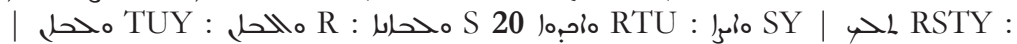

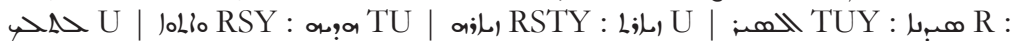

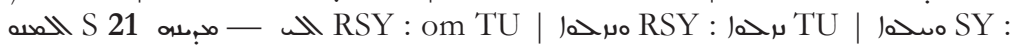
om. RT : سحه | RS RS : om. TU 


\section{Garšūnī B}

4 مصل aلم

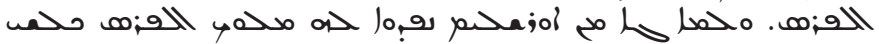

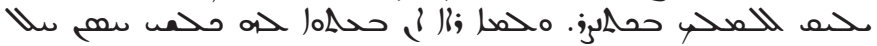

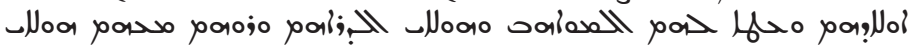
15

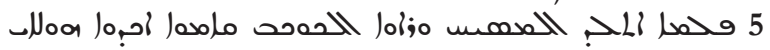
الح:

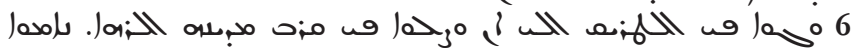

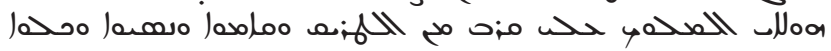




\section{Garšūnī A}

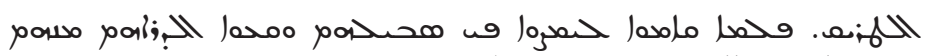

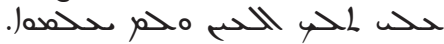

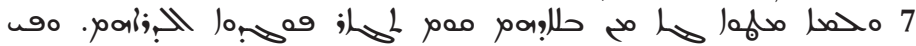

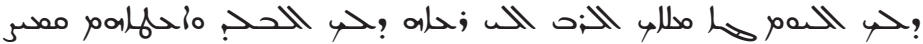

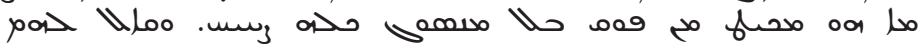

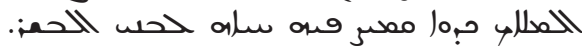

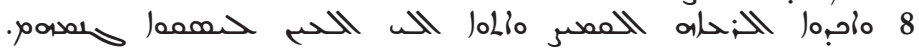

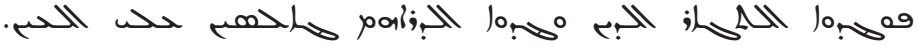

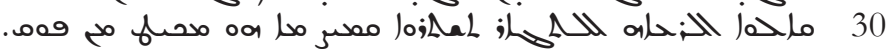

\section{RSTUY}

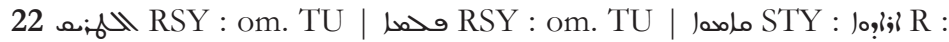

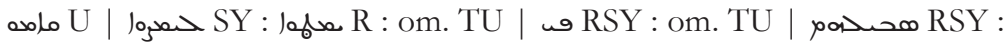

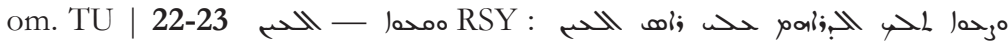

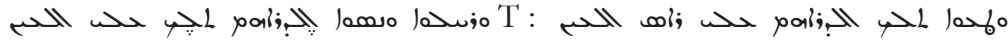

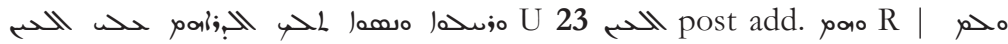

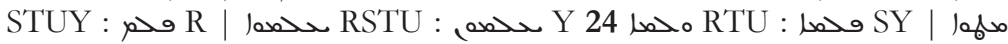

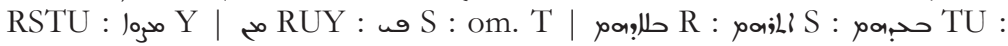

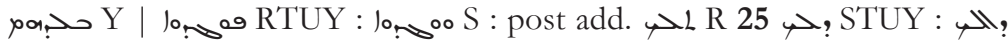

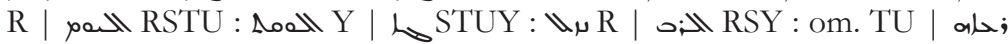

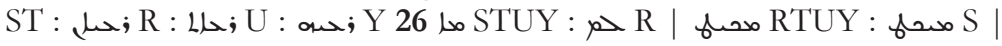

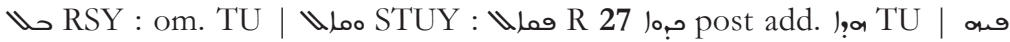

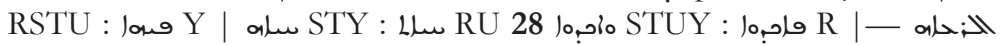

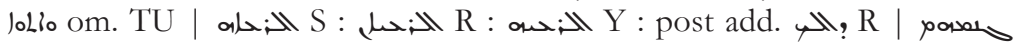

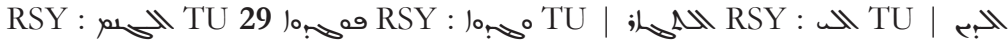

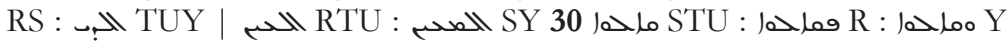

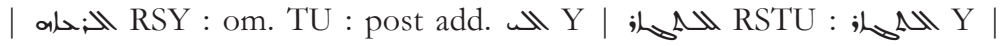

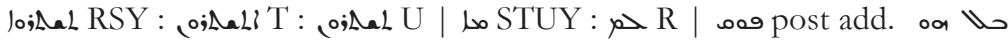
مخه منחم: : Y 


\section{Garšūnī B}

20

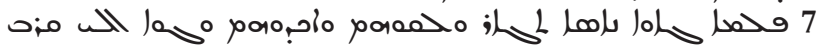

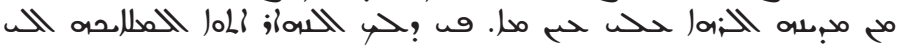

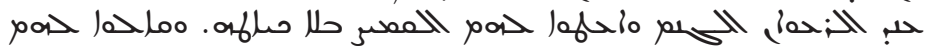

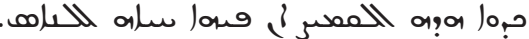

25

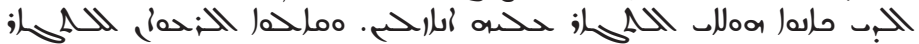

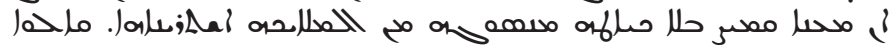




\section{Garšūnī A}

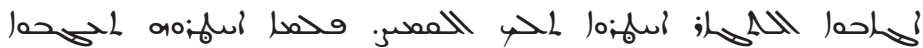

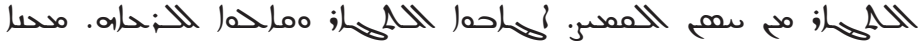

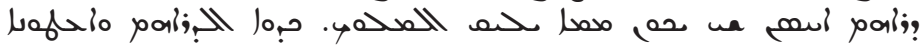
الحمد.

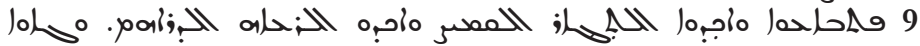

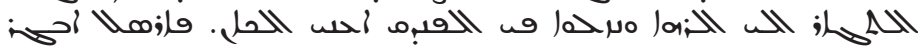

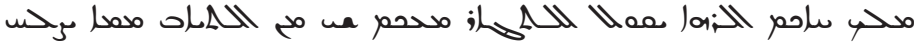

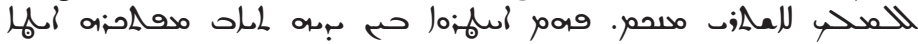
الحمد.

\section{RSTUY}

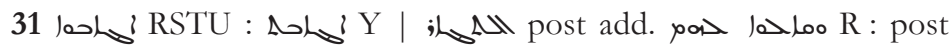

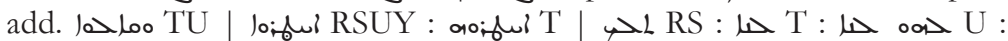

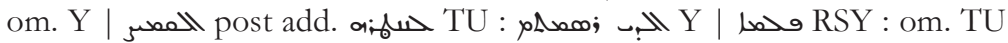

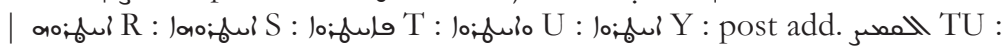

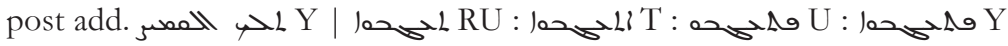

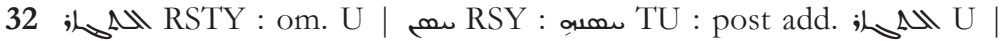

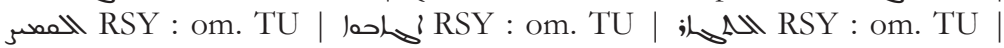

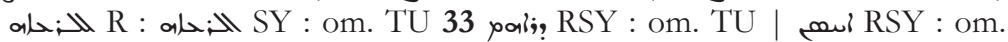

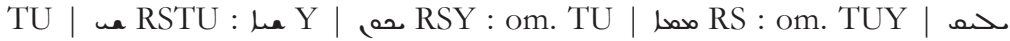

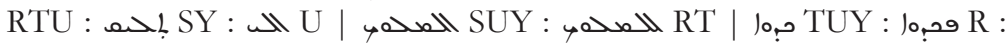

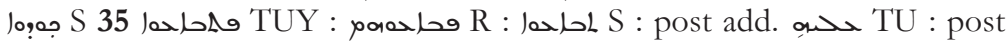

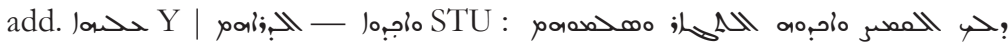

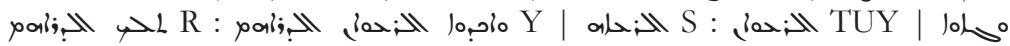

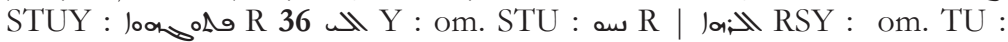
ante add. مبر R | الحصبم RUY : الحمل RT : post add. o fin. lin. R (haplog.?) | أحس SUY : om. R : om. T | الحمل UY : om. R : الحمبرم : S : الحمبرم : in marg.

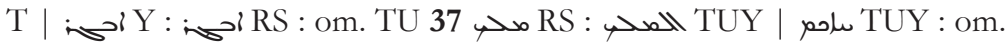

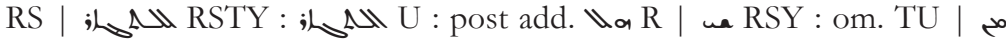

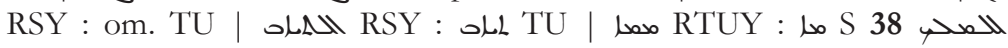

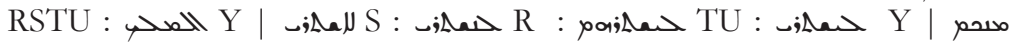

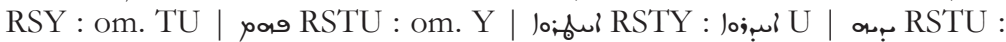

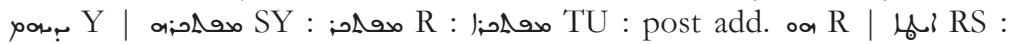

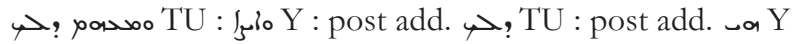




\section{Garšūnī B}

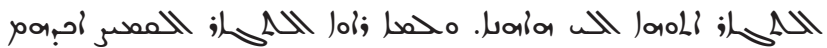

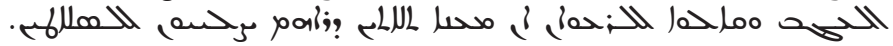
30

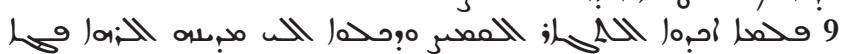

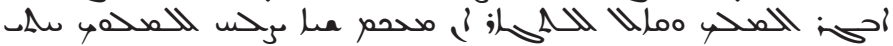
ilai 


\section{Garšūnī A}

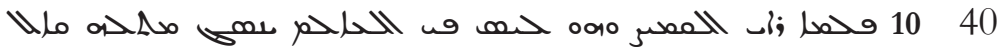

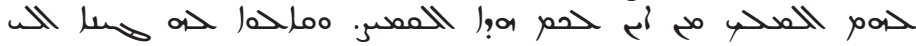

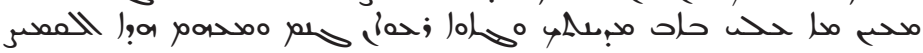

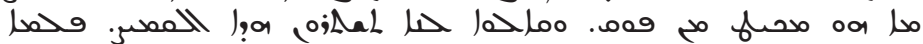

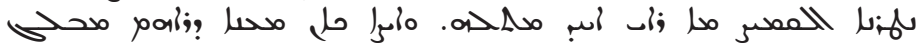

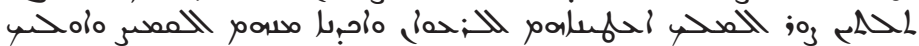

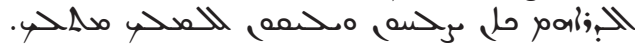

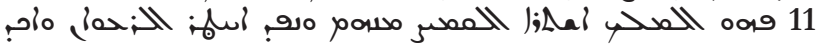

\section{RSTUY}

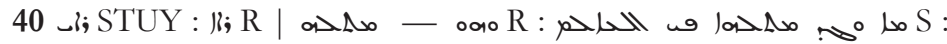

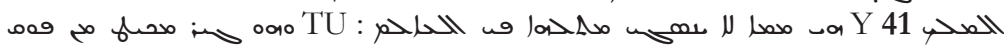

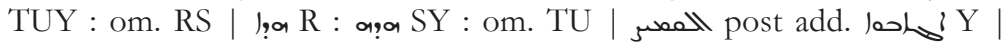

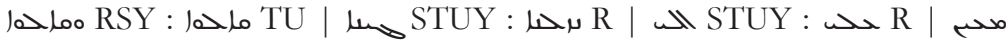

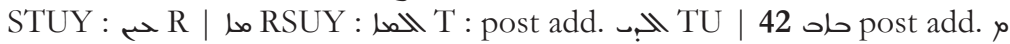

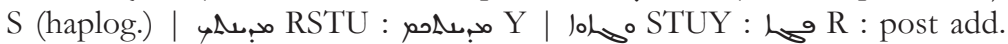

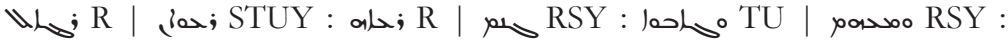

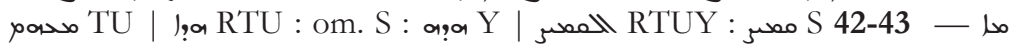

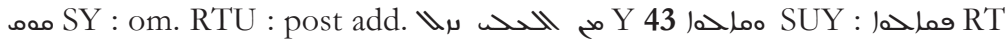
| o;Aal STU : lo;Aai R : lo;Aal Y | laa RTU : a,a SY | هحما STUY : om. R

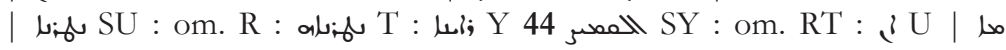

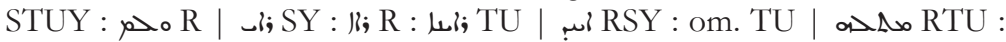

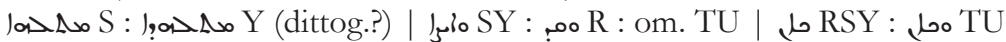

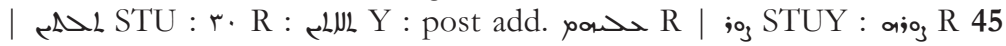

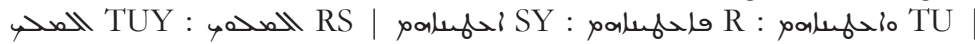

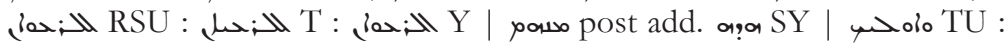

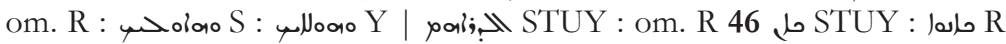

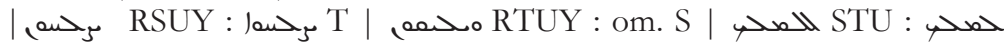

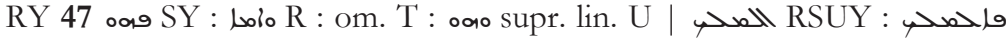

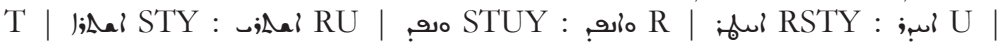

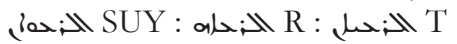




\section{Garšūnī B}

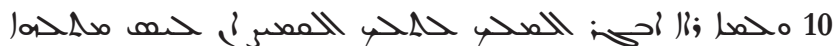

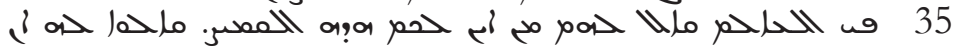

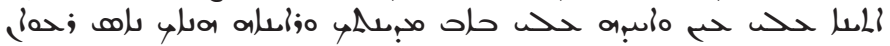

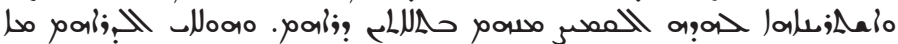
ملها

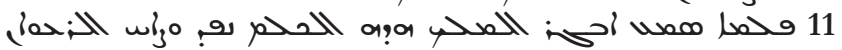
pio 


\section{Garšūnī A}

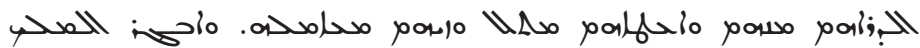

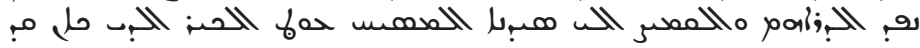
50 12 فحما 12

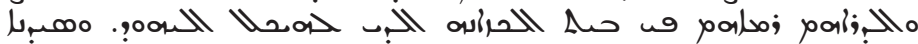

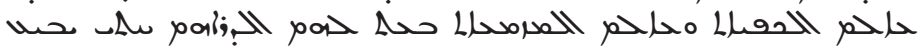
حمar

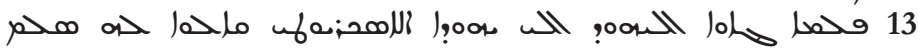
55

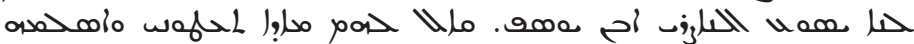

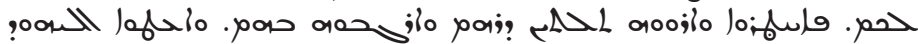
الخ:

\section{RSTUY}

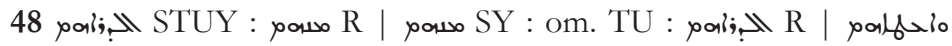

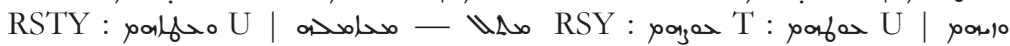

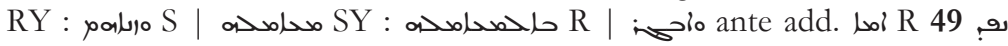

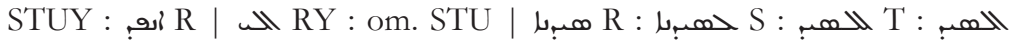

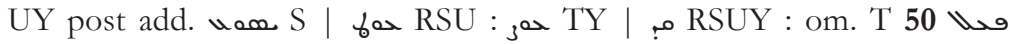

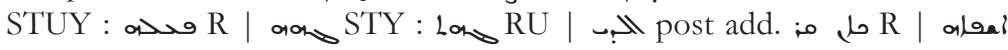

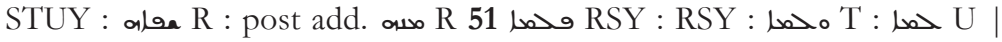

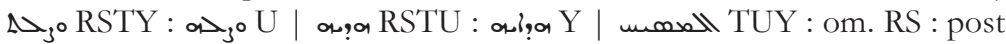

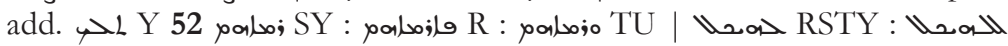

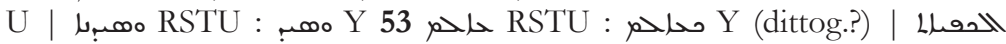

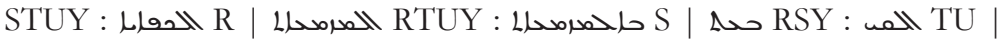

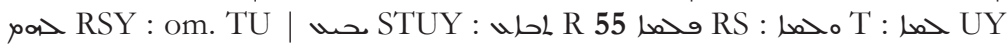

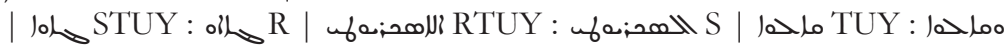

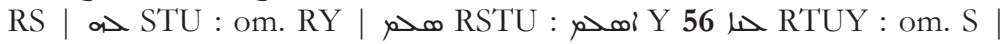

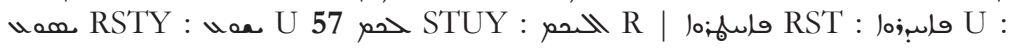

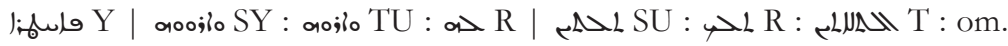

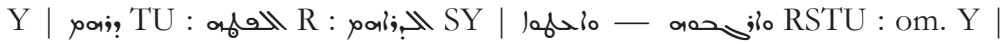

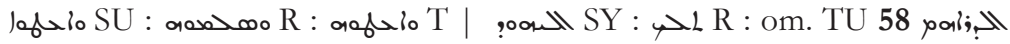

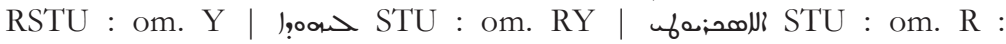
حلامص:- $\mathrm{Y}$ 


\section{Garšūnī B}

40

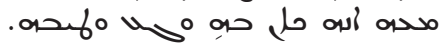

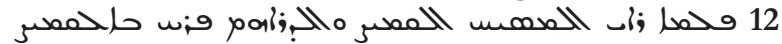

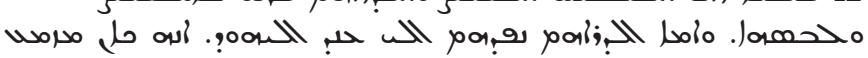

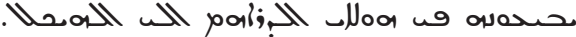

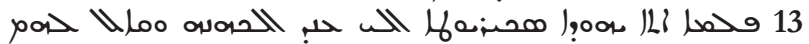

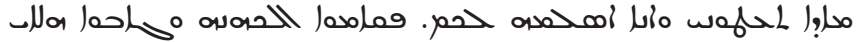

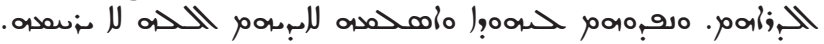

$\mathrm{V}$

40 I supr. lin. 


\section{Garšūnī A}

14 60

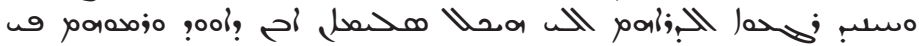

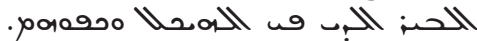

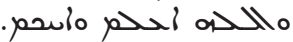

\section{RSTUY}

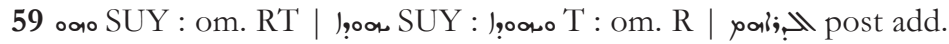

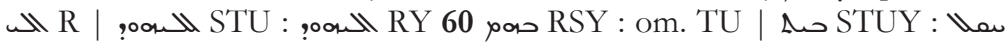

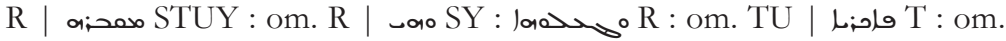

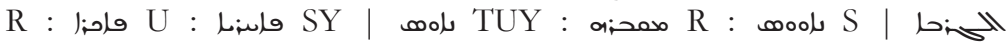

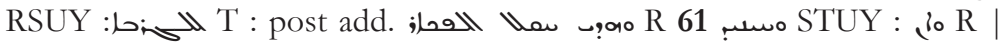

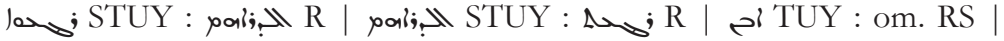

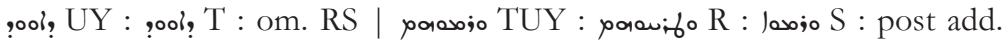

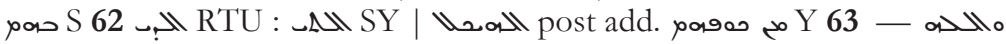

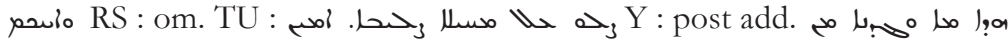
أم: الl: R 


\section{Garšūn̄̄ B}

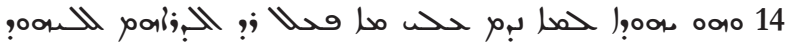

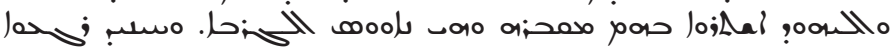

$$
\begin{aligned}
& 50 \\
& \text { po0900 لhall }
\end{aligned}
$$

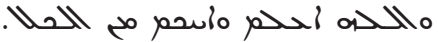




\section{Garšūnī A}

The story of the origin of the pieces which Judas Iscariot took as the price of our Lord the Christ. ${ }^{1}$

1 It is said ${ }^{2}$ of the pieces ${ }^{3}$ that Judas took from the Jewish priests that Terah, the father of Abraham, ${ }^{4}$ minted these ${ }^{5}$ pieces and gave them to Abraham. Abraham also ${ }^{6}$ gave them to his son Isaac and Isaac bought a village with them. The master of the village ${ }^{7}$ used them to honor Pharaoh. ${ }^{8}$

2 Pharaoh sent them ${ }^{9}$ to Solomon son of David as a gift on the occasion of the construction of the Temple. And Solomon ${ }^{10}$ put them on the frame of the door to the Sanctuary, ten on the upper frame, ten on the left and ten on the right. ${ }^{11}$

${ }^{1}$ This wording is found in S. R has "And we write the report of the silver that Judas took from the Jews as the price of our Lord Jesus Christ, may his memory be worshipped and praised." TU lack a title. Y has "By the power of the Holy Trinity, we write here the story of the origin of the pieces that Judas Iscariot took as the price of our Lord the Messiah, may he be worshipped and praised."

${ }^{2} \mathrm{~T}$ has "some scholars say." $\mathrm{U}$ has "... a report about them, some scholars say." $\mathrm{Y}$ adds "my brothers."

${ }^{3} \mathrm{R}$ has "silver."

${ }^{4}$ TUY add "the Companion," a traditional Arabic title for Abraham (cf. GarB).

5 TU have "the."

${ }^{6} \mathrm{R}$ lacks this word.

${ }^{7} \mathrm{R}$ adds "took the sum of the pieces."

8 TU add "the king."

${ }^{9} \mathrm{R}$ has "gave them."

${ }^{10} \mathrm{R}$ has a lacuna at "son ... Solomon."

${ }^{11}$ For "ten on the left and ten on the right," RSY have "ten here and ten here" and Thas "ten on the left side." 


\section{Garšūnī B}

By the power of the Holy Trinity, we write (the story) of the origin of the pieces which Judas took as the price of our Lord.

1 They say about the pieces that Judas took from Jewish priests that Terah the father of Abraham the Companion ${ }^{12}$ minted these coints and gave them to Abraham. Abraham also gifted them to Isaac his son and Isaac bought with them a village. The master of the village gave them as tribute to Pharaoh.

2 Pharaoh sent them to Solomon, the son of David, as a gift on the occasion of the construction of the Temple. Solomon put them on the frame of the door to the Sanctuary, ten on the upper frame, ten there and ten there.

12 A traditional Arabic title for Abraham. 


\section{Garšūnī A}

3 When Nebuchadnezzar the king of Persia ${ }^{13}$ came and took captive the children of Israel, ${ }^{14}$ he entered the Temple of Solomon ${ }^{15}$ and saw the pieces and found them beautiful. ${ }^{16}$ He took them to Babylon with the rest of the children of Israel.

$4 \mathrm{He}$ had there children of the king of Persia as hostages. ${ }^{17}$ And when he returned from Jerusalem, the kings of Persia sent him many treasures ${ }^{18}$ and brought all kinds of things worthy of kings. And when Nebuchadnezzar saw that they had sent him tribute worthy of rulers, he released their children and gave them many gifts. He also gave them these pieces with the rest of the gifts and the children of Persia went with the pieces ${ }^{19}$ to their fathers.

5 When our Lord $^{20}$ Jesus $^{21}$ Christ $^{22}$ was born and they saw the star, ${ }^{23}$ they rose and took with them ${ }^{24}$ gold, myrrh and frankincense.

${ }^{13}$ The WSyr Mss D and E also refer to Nebuchadnezzar as "king of the Persians." See above, note 4.

${ }^{14} \mathrm{R}$ adds "from Jerusalem."

${ }^{15} \mathrm{Y}$ adds "son of David."

${ }^{16}$ Lit. "they were pretty in his eye." TY have "in his eyes."

${ }^{17}$ TU has "who served him"; Y lacks "as hostages."

${ }^{18} \mathrm{R}$ has "honored him"; TU lack "And ... treasures."

${ }^{19}$ SY have "with these pieces."

20 TUY lack "our Lord."

${ }^{21}$ RTUY lack "Jesus."

${ }^{22} \mathrm{Y}$ adds "may his memory be worshipped and praised and hallowed and venerated."

${ }^{23}$ TU add "as foretold by Bal'am, their grandfather" (cf. "prophecy of Zarathustra" in ESyr).

${ }^{24}$ TU have "in their bags." 


\section{Garšūnī B}

3 When Nebuchadnezzar the king of Persia came and took the children of Israel captive, he entered Solomon's temple and saw these pieces and found them beautiful. He took them as ransom ${ }^{25}$ with the rest of the captive children of Israel.

4 And he had there in the city of Babylon some Persian youths whom he had captured as hostages. When he came from Jerusalem, the kings of Persia sent all (kinds of) things worthy of kings to king Nebuchadnezzar. When he saw that they had sent him all (kinds of) beautiful things, he let their children go and gave them gifts and these pieces and he sent them with these Persians to their fathers.

5 When Christ was born and they saw the star, they rose and took these pieces and myrrh, gold and frankincense.

${ }^{25}$ Lit. "blood money." 


\section{Garšūnī A}

6 And they also took these pieces and went to visit the Lord 26 Christ. When they came to the vicinity of the city of Edessa, they set down and stopped at a well in the road. ${ }^{27}$ When they got up ${ }^{28}$ to continue their journey, ${ }^{29}$ the pieces fell from them on that well ${ }^{30}$ without them knowing.

7 When they left, there came from their country ${ }^{31}$ some merchants and they found the pieces. That very day, ${ }^{32}$ an angel of the Lord ${ }^{33}$ came to shepherds of that country and gave them a robe without a seam on the upper end made of one piece. And the angel said to them, "Take this robe, for in it is the life of humanity."

8 So the shepherds took the robe and came to the well to give water to their sheep ${ }^{34}$ and they fund the merchants ${ }^{35}$ who had found the pieces sitting on the well. The shepherds said to the merchants, "Will you buy a robe without a seam on the upper end?" The merchants replied, "Bring that robe." 36 When they brought it, ${ }^{37}$ the merchants marveled at the beauty of the robe. The merchants replied and said to the shepherds: "We have some pieces that are the most beautiful thing (of all things that are) worthy a king. Take the pieces and give us the robe."

$26 \mathrm{R}$ has "our Lord"; S has an unidentified word.

27 TU lack "in the road."

${ }^{28} \mathrm{R}$ has "they wanted."

29 TU lacks "their journey."

${ }^{30}$ Instead of "the pieces ... well", TU have "they put the pieces on the well and forgot these pieces on the well."

31 S has "in their footsteps"; TU have "after them."

32 Y has "at that time."

33 TU lack "of the Lord."

34 TU lack "the shepherds ... came."

35 TU have "those."

36 TU add "so that we can look at it," Y adds "that you described."

${ }^{37}$ TU add "the robe," Y adds "that robe." 


\section{Garšūn̄̄ B}

6 And they went on their way until they arrived in the vicinity of the city of Edessa. These kings then slept at the side of the road. When they got up they forgot and left the pieces remembering nothing about their real value.

7 When some merchants came, they found them and took them and came to the vicinity of the city of Edessa to a well. On that day, angels came to shepherds and gave them a robe without a seam and said to them, "Take this robe, the life of humanity is in it."

8 These shepherds took the robe and came to the well at which these merchants stopped. And the shepherds said to the merchants, "We have a robe woven without a seam (that we received) from angels. Buy it from us." 38 The merchants said, "Bring it here." And when the merchants saw the robe, awe overtook them and they said to the shepherds, "We have thirty pieces fit for rulers. Take them and give us the robe."

${ }^{38}$ Lit. "We bought it," clearly an error. 


\section{Garšūnī A}

9 And so they concluded the transaction and the merchants took the robe and the shepherds took the pieces. ${ }^{39}$ The merchants went to Edessa ${ }^{40}$ and stopped at an inn, that is, ${ }^{41}$ a roadhouse. ${ }^{42}$ Abgar, ${ }^{43}$ the wise ${ }^{44}$ king of Edessa, sent for them and said to the merchants, "You ${ }^{45}$ have an item of clothing that is fit for a king that I (want to) buy from you." 46 And they brought in their ${ }^{47}$ hands magnificent dresses and also the ${ }^{48}$ robe.

10 When the king ${ }^{49}$ saw the robe of which there was no other like it made in the world, ${ }^{50}$ he said to the merchants, "Where did you get this ${ }^{51}$ robe?" They said ${ }^{52}$ to him, ${ }^{53}$ "We came to a well at the gates to your ${ }^{54}$ city and there came some shepherds with this ${ }^{55}$ robe without a seam on the upper end. ${ }^{56}$

${ }^{39}$ For "the merchants ... the pieces," $\mathrm{R}$ has "over that robe and the merchants took it and they handed them those pieces" and Y has "the shepherds took the pieces."

40 T has "city of Edessa."

41 RT lack "that is"

${ }^{42}$ ST transpose "roadhouse" and "inn." Note that WSyr also mentions the inn, but ESyr does not.

43 TU do not give the name.

${ }^{44} \mathrm{RS}$ lack this word.

45 R has "do you."

46 TU lack "from you."

${ }^{47}$ Lit. "his hands," only Y has "their hands."

48 TU have "that."

${ }^{49}$ RS lack "the king."

${ }^{50} \mathrm{~S}$ has "no other like it could be found in the world"; TU have "which was without a seam on the upper end."

51 TU have "the."

${ }^{52} \mathrm{Y}$ has "they answered and said."

53 This longer exchange features in WSyr as well.

${ }^{54}$ RSTU have singular, Y has plural.

55 TU have "the."

${ }^{56}$ RTU lack "without ... end," Y adds "that came down from above." 


\section{Garšūnī B}

9 When the merchants took the robe and entered the city of Edessa, king Abgar came and said to the merchants, "You have something fit for a king that I (am to) buy from you." The merchants said, "We have a robe without a seam on the upper end."

10 When Abgar saw that robe of which there was no like it in the world, he said to them, "Where did you get this robe?" They said to him, ${ }^{57}$ "We came upon a well at the gates to your city and saw it there with some shepherds and bought it from them for thirty pieces. And these pieces are surely fit for a king such as yourself."

${ }^{57}$ This short exchange between Abgar and the merchants is also a feature of ESyr. 


\section{Garšūnī A}

They said to us, 'Will you buy this robe?' When ${ }^{58}$ we saw the robe, (we knew that) none ${ }^{59}$ had ever seen one like it. We also ${ }^{60}$ had some pieces in the sum of thirty ${ }^{61}$ images of kings ${ }^{62}$ that we gave to the shepherds and we took from them the ${ }^{63}$ robe. And those pieces were fit for and worthy of a king such as yourself.

11 The king bought the robe from them and sent for the shepherds to be brought. He took from them the pieces and gave them their equivalent in weight in exchange. ${ }^{64}$ And Abgar the king sent the pieces and the robe to our ${ }^{65}$ Lord the Messiah in return for the good that he had done to him with respect to a strong pain from which he had cured him.

12 When the king's gift arrived, our Lord the Messiah ${ }^{66}$ took the ${ }^{67}$ robe. As for the pieces, he threw them into the treasury that is in the Jewish Temple. Our Lord, ${ }^{6}$ knowing (all) the secrets and knowing the predestined, ${ }^{69}$ he sent them the pieces $^{70}$ to buy himself with them.

\footnotetext{
${ }^{58} \mathrm{R}$ lacks this word.

59 TU lack this word.

${ }^{60}$ RTU lack this word.

${ }^{61} \mathrm{R}$ has 30 written in Arabic digits.

62 These "images of kings" are also mentioned in WSyr.

63 SY have "this."

${ }^{64}$ For "their ... exchange," TU have "in return."

65 TUY have "the."

${ }^{66}$ RS lack "the Messiah."

67 Y has "this."

${ }^{68}$ Y has "the Lord."

${ }^{69}$ This mention of Jesus knowing "secrets" is also featured in WSyr.

70 TU have "handed the pieces."
} 


\section{Garšūn̄̄ B}

11 When Abgar heard these words, he sent and called for the shepherds and took the pieces and the robe. (Abgar) sent them to the Christ because of the good he had performed on him when he suffered from a pain and he healed him.

12 When Christ saw the robe and the pieces, he was happy over the robe and put it on. As for the pieces, he sent them to the Jews, for it was destined that they would buy him with ${ }^{71}$ these pieces to the Temple.

${ }^{71}$ Lit. "in." 


\section{Garšūnī A}

13 And when the Jews came to Judas Iscariot, they said to him, ${ }^{72}$ "Deliver to us Jesus the Nazarene, the son of Joseph." "73 He said to them, "What will you give me if I deliver him to you?" So they brought and showed ${ }^{74}$ him thirty pieces ${ }^{75}$ and awakened his greed with them. And the Jews ${ }^{76}$ gave $^{77}$ the pieces to Judas ${ }^{78}$ Iscariot. ${ }^{79}$

14 When Judas repented what he had done, he returned the pieces to the Jews. And the Jews bought with them ${ }^{80}$ a cemetery which was a potter's land as a burying place for strangers. ${ }^{81}$ At that time, they returned the pieces ${ }^{82}$ to the Temple of Solomon son of David $^{83}$ and they threw them into a well which is in the Temple ${ }^{84}$ and hid them. ${ }^{85}$

But only God is all-knowing. ${ }^{86}$

72 RY lack "to him."

${ }^{73}$ This dialogue between the priests and Judas is similar to that in WSyr.

${ }^{74} \mathrm{R}$ lacks "and showed."

75 R has "silver."

76 TU have "they."

${ }^{77} \mathrm{R}$ has "handed."

${ }^{78}$ RY lack "Judas."

${ }^{79}$ Y lacks "gave the pieces to Judas."

80 TU lack "with them."

${ }^{81} \mathrm{R}$ has "bought with them a field which they made into a cemetery for strangers and this is the potter's field."

${ }^{82} \mathrm{R}$ has "the pieces returned."

${ }^{83}$ RS lack "the son of David."

${ }^{84} \mathrm{Y}$ adds "out of fear."

${ }^{85}$ The hiding of the pieces in the well is found also in WSyr, though WSyr mentions the staff of Moses as well. The presence of this element in both WSyr and GarA (but not ESyr or GarB which shares some properties of ESyr) suggests that it is original to the text.

86 TU lack this traditional formula. Y has "Pray for the weak and the cross, amen" in Syriac. R adds: "This is what we found about the matter of the pieces and the robe. May God look favorably upon this undertaking and grant us his mercy forever, amen." 


\section{Garšūnī B}

13 When Judas Iscariot came to the priests and said to them "What will you give me if I deliver him to you?" the priests rose and brought these pieces. They sent them to Judas and he delivered him to their hands, may God have mercy on him.

14 When Judas repented what he had done, he returned the pieces to the Jews and the Jews bought with them a cemetery which is a burying place for strangers. At that time, they returned the pieces to Solomon's Temple and threw them into a well which is in the Temple and hid them.

But only God is all-knowing. 
